\title{
Radiation-Grafted Polymer Electrolyte Membranes for Fuel Cells
}

\section{Yakıt Pilleri için Radyasyonla Aşılanmış Polimer Elektrolit Membranlar}

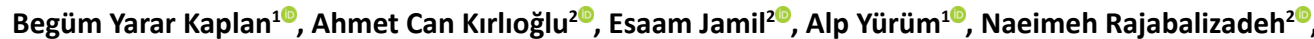 \\ Navid Haghmoradi ${ }^{2}{ }^{\oplus}$ Bilal Iskandarani ${ }^{2}$, Hamed Salimkhani ${ }^{2 \oplus}$ and Selmiye Alkan Gürsel ${ }^{1,2^{*} \odot}$ \\ ${ }^{1}$ SabancI University Nanotechnology Research and Application Center (SUNUM), Istanbul, Turkey. \\ ${ }^{2}$ Faculty of Engineering and Natural Sciences, Sabancı University, Istanbul, Turkey.
}

\section{ABSTRACT}

- uel cells are one of the most efficient energy conversion systems to produce electricity. A solid ion-conducting polymer - membrane is employed as both separator and electrolyte for polymer electrolyte membrane fuel cells and anionexchange membrane fuel cells. Radiation-induced graft polymerization is a versatile method for the fabrication of low-cost alternatives to commercial polymer membranes. In this method, typically a base polymer is exposed to ionizing radiation which generates active radical sites within the polymer substrate. Then a suitable vinyl monomer is polimerized on these active sites to form a graft copolymer. Finally, a subsequent chemical treatment is performed to introduce hydrophilic groups to hydrophobic polymer backbone so that an ion conducting membrane is formed. There are various studies about the influence of radiation grafting parameters on membrane properties. Moreover, the favorable fuel cell relevant and polarization properties of such radiation-grafted membranes were reported. Thus, radiation-grafted polymer membranes are one of the significant low-cost alternatives for fuel cells. This review focuses on the preparation, characterization of fuel cell relevant properties and fuel cell performance of radiation-grafted membranes.

\section{Key Words}

Polymer electrolyte, membrane, radiation-induced grafting, fuel cell.

\section{öz}

\begin{abstract}
Vakıt pilleri elektrik üretimi için kullanılabilecek en verimli enerji çevrim sistemlerinden biri olarak kabul edilmektedir. Polimer elektrolit membranlı yakıt pilleri ve anyon değişim membranlı yakıt hücreleri için hem ayraç hem de elektrolit olarak katı iyon iletken bir polimer membran kullanılmaktadır. Radyasyonla aşı polimerizasyonu, ticari polimer membranlar için düşük maliyetli alternatiflerin üretimi için kullanılan çok yönlü bir yöntemdir. Bu yöntemde, tipik olarak bir baz polimer, polimer substrat içinde aktif radikal bölgeleri oluşturan iyonlaştırıcı radyasyona maruz bırakılır. Ardından uygun bir vinil monomeri bu aktif bölgeler üzerinde polimerleştirilir. Son aşama olarak, hidrofobik polimer çatısına hidrofilik grupların eklenerek iyon iletken bir membran oluşturulması için son bir kimyasal işlem yapılır. Radyasyonla aşılama parametrelerinin membran özelliklerine etkisi konusunda çeşitli çalışmalar vardır. Ayrıca, bu tür radyasyonla aşılanmış membranların, yakıt pili ile ilgili elverişli özellikleri ve polarizasyon özellikleri rapor edilmiştir. Bu nedenle, radyasyonla aşılanmış polimer membranlar, yakıt pilleri için önemli düşük maliyetli alternatiflerden biridir. Bu derleme, radyasyonla aşılanmış membranların hazırlanması, yakıt pili ile ilgili özelliklerinin ve yakıt pili performanslarının karakterizasyonlarına odaklanmaktadır.
\end{abstract}

\section{Anahtar Kelimeler}

Polimer elektrolit, membran, radyasyonla aşılama, yakıt pili.

Article History: Received: Sep 15, 2020; Revised: Sep 20, 2020; Accepted: Oct 20, 2020; Available Online: Oct 20, 2020.

DOI: https://doi.org/10.15671/hibc.813239

Correspondence to: S. Alkan Gürsel, Faculty of Engineering and Natural Sciences, Sabancı University; and Sabancı University Nanotechnology Research and Application Center (SUNUM), Istanbul, Turkey.

E-Mail: selmiye@sabanciuniv.edu 


\section{INTRODUCTION}

E uel cells are electrochemical devices that convert chemical energy directly into electrical energy. This clean and efficient technology has the capacity to produce electricity and heat. Polymer electrolyte membrane fuel cells (PEMFC), operating at low temperatures (below $100^{\circ} \mathrm{C}$ ), have been accepted as one of the most efficient types of fuel cells and they found application in various areas for stationary and portable power generation. Transportation is another area of application of PEMFC and the Toyota Mirai fuel cell car is one of the best examples in this regard. Despite PEMFC powered systems are now on the market, there are significant barriers to the commercialization of this technology. The high cost (mainly due to precious metal catalysts used), durability and the lack of hydrogen infrastructure are still the core challenges of PEMFC. Operation at temperatures above $100^{\circ} \mathrm{C}$ is a strategy to enhance the utilization of catalyst and efficiency and thus to reduce the cost of PEMFC. Moving from acid to alkaline fuel cell which allows using nonprecious metals as catalysts is another attractive option. In this regard, anion-exchange membrane fuel cells (AEMFC) has become a remarkable avenue of fuel cell research in the last decade.

Polymer electrolyte membrane, acting as both separator and electrolyte, is one of the most crucial components of PEMFC and AEMFC. There are commercial membranes in the market, especially for PEMFC. Due to their excellent conductivity and stability, Nafion ${ }^{\circledR}$ membranes and derivatives have been extensively employed in PEMFC. However, Nafion has various limitations including its poor performance and degradation at high temperatures and low humidity conditions and high cost due it is complicated synthesis procedures. In the case of AEMFC, only a few commercial membranes are available and AEMs with higher chemical stability are needed. Therefore, significant research is being conducted to develop low-cost alternatives to Nafion membranes for PEMFC and high stability AEMs for AEMFC.

Radiation-induced grafting offers the promise of the preparation of alternative polymer membranes for both PEMFC and AEMFC. It is a versatile method to modify polymers with irradiation and introduce certain functionalities. A very large number of experimental investigations of a quite wide variety of radiation-grafting systems have been reported in the literature. There are various studies about the influence of radiation grafting parameters on membrane properties. In this article, radiation grafted polymer membranes and fuel cells are introduced and examples from our group and literature are reviewed in this paper. The ultimate aim of this review is to provide some basic background regarding radiation-grafted polymer membranes for PEMFC and AEMFC technology.

\section{Fuel Cells}

The decline of fossil fuels has provoked a rising concern regarding the future of energy generation. In this regard, the global society has started a quest for alternative energy resources, more specifically, cleaner energy resources. One of the technologies that seem promising to become commercialized in near future is fuel cells. Fuel cells directly convert chemical energy into electrical energy. This clean and efficient technology has the capacity to produce electricity and heat. High efficiency (up to 60\%), less pollutant like sulfur and nitrogen oxides, and fewer $\mathrm{CO}_{2}$ are the attracting characteristics of fuel cells.

After the invention of the first fuel cell by Sir William Robert Grove in 1838, it took almost one century until the practical usage of fuel cells started. In 1962, General Electric used its commercial fuel cell in the Gemini space mission. There is a wide range of applications for fuel cells: large scale power generation; combined heat and power source; off-grid and backup power services; transportation application; and portable applications.

Since the terms electrical and chemical energy are combined in fuel cells, like other electrochemical systems, fuel cells comprise a package of two electrodes (anode and cathode), an electrolyte and a conducting wire which links the electrodes (Figure 1). By fueling the fuel cell (with hydrogen, methanol etc.) a potential gradient between two electrodes will be created (by charged ions passing through the electrolyte). This potential gradient is the main source of the electric current in the external circuit. The difference between various fuel cell systems stems from primarily the fact that they use a different electrolyte. The fuel required, operation temperature, reactions that occur and some other factors are determined accordingly.

PEMFC have stood tall for ages as a source of energy taking the advantage of hydrogen as an energy reservoir that can probably substitute for currently used 
fossil fuels [1]. PEMFC offer certain advantages including low-temperature operation, high power density, relatively small size, fast start-up and response time and low cost. PEMFC are generally composed of two separate electrodes (a negative anode and a positive cathode) having an electrically insulating yet ion-conducting membrane in between. This assembly is widely regarded as the membrane electrolyte assembly (MEA) and is considered as the pounding heart of any PEMFC that have a direct correlation with the efficiency of a fuel cell [2]. The main problems of MEA are: i) commonly used perfluorosulfonic acid-based membrane (such as commercial Nafion membrane) is very expensive, its ionic conductivity is strongly dependent on the humidity of the environment and degrades easily under low humidity conditions, and ii) Pt which is used as a catalyst in electrode structure is very expensive and its reserves are limited. Therefore, the commercialization of PEMFC is becoming problematic.

So far, three main areas of energy consumption fields have been interested in PEMFC technology. Transportation, back up powers, and somehow portable devices are the subjects that have challenged researchers for high performing and cheaper PEMFC. The main barrier in commercializing PEMFC is the high production costs. Among different applications of PEMFC, back-up power for telecommunication and financial companies has gained increasing interests due to the significantly high cost of the power breakdown that may compensate for the high cost of PEMFC in this area. The third category of PEMFC technology is providing electricity for portable devices like small APUs for boats and lightening, and military applications.

Anion-exchange membrane fuel cells (also known as alkaline fuel cells, anion exchange membrane alkaline fuel cells, and solid alkaline fuel cells in the literature) (AEMFC), another significant fuel cell technology, offering lower cost because of comparably cheaper components including both membrane and catalyst. The working principle of AEMFC is similar to PEMFC. However, the main difference between these two systems is the nature of their conductive ion. In PEMFC, $\mathrm{H}^{+}$ions are transported across the membrane while in AEM fuel cells, $\mathrm{OH}^{-}$ions are conducted. The functioning mechanism of AEM fuel cells is such that $\mathrm{O}_{2}$ is, first, reduced at the cathode side and, then, reacts with water to form reduced $\mathrm{OH}^{-}$ions. These $\mathrm{OH}^{-}$ions are, hence, transferred from the cathode to anode by the anion exchange membrane and, further, react with $\mathrm{H}_{2}$ fuel at the anode side. As a result of such electrochemical reactions, chemical energy is converted into electrical energy and water is released as a by-product [3]

On the other hand, AEMFC operate the reverse of PEMFC. First, the reduction reaction of oxygen takes place at the cathode side and, then, this product is transferred to the membrane by being reduced to $\mathrm{OH}$ ions:

$1 / 2 \mathrm{O}_{2}+\mathrm{H}_{2} \mathrm{O}+2 \mathrm{e}^{-} \rightarrow 2 \mathrm{OH}^{-}$

Further, $\mathrm{OH}^{-}$ions carried along the anion exchange membrane reach the anode and are oxidized to $\mathrm{H}_{2} \mathrm{O}$ :

$2 \mathrm{OH}^{-}+\mathrm{H}_{2} \rightarrow 2 \mathrm{H}_{2} \mathrm{O}+2 \mathrm{e}^{-}$

Due to the disadvantages and limitations of PEMFC such as their high cost of production (need for expensive Pt catalysts), low electrode kinetics, high fuel permeability, and $\mathrm{CO}$ poisoning of $\mathrm{Pt}$ and Pt-based catalysts at low temperature [4], there has been a significant increase in the number of articles and research on AEMFC in the last decade. Such growing interest in AEMFC compared to PEMFC stem from the numerous advantages concerned with the alkaline $\mathrm{pH}$ environment [5] as mentioned below:

i) Advanced oxygen reduction reaction catalysis with Pt free and inexpensive catalysts.

ii) Providing a wide range of fuel cell and stack materials

iii) A wide range of fuel options in addition to pure $\mathrm{H}_{2}$ (for instance; 'dirty' $\mathrm{H}_{2}$ such as including hydrazine hydrate and scarce amount of ammonia)

Besides that, AEMFC provide fast electrode kinetics due to their high $\mathrm{pH}$ working environment, eliminating the need for Pt catalysts, and the use of cheaper materials for a membrane electrode assembly (MEA).

A solid polymer membrane is employed in both PEMFC and AEMFC (Figure 2). In those fuel cell cells, the membrane has a dual function. First, it is employed as the separator to divide the fuel cell into two parts. On one side, hydrogen as the fuel is introduced (anode) and on the other side the oxygen as the oxidant (cathode). Second, the membrane is utilized as the electrolyte. Gases (oxygen and hydrogen) cannot go through this membrane, but the membrane can transfer proton or hydroxide 


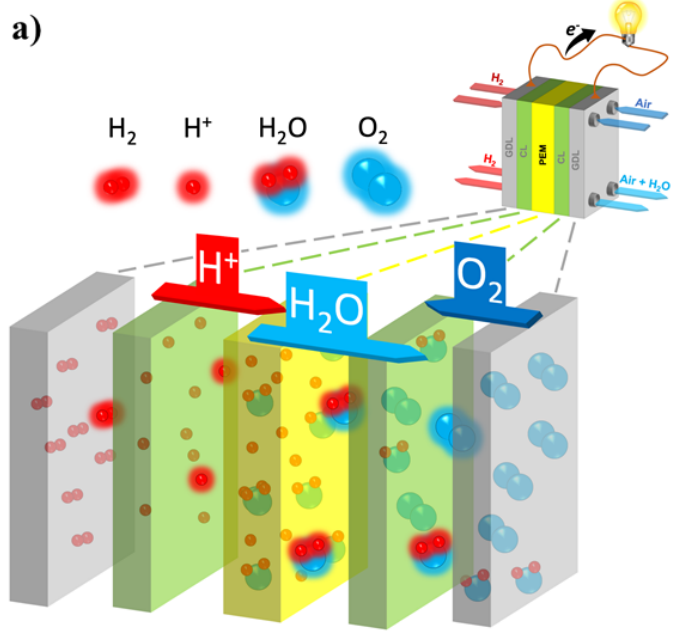

Figure 1. Schematics of PEMFC (a) and AEMFC (b).

ion from anode to cathode since it has an ion-conducting functionality. The membrane thickness generally between 5 to $200 \mu \mathrm{m}$ for fuel cells.

\section{Radiation-Induced Graft Polymerization}

Radiation-induced graft polymerization (or radiation-induced grafting) is mainly utilized for the modification of solid polymeric materials in the form of film or powder. Radiation-induced grafting provides the combination of appealing properties of different polymers to form a new material as well. For instance, it is possible to use hydrophobic polymers as the backbone together with hydrophilic polymers to form polymer electrolyte membranes.

In this process, a base polymer is simply treated with high energy radiation to create active reaction centers in the polymer backbone (Figure 3). Gamma ray, X-rays or electron beam in vacuum, air or inert atmosphere can be used for that purpose. The active center, usually a free radical, acts as the main initiation site for the graft polymerization of monomers onto the base polymer. Once a graft copolymer is obtained, it is necessary to introduce functionality to provide ion conduction. Sulfonation, phosphonation, treatment of phosphoric acid or amination are performed to yield an ion-conducting polymer membrane.

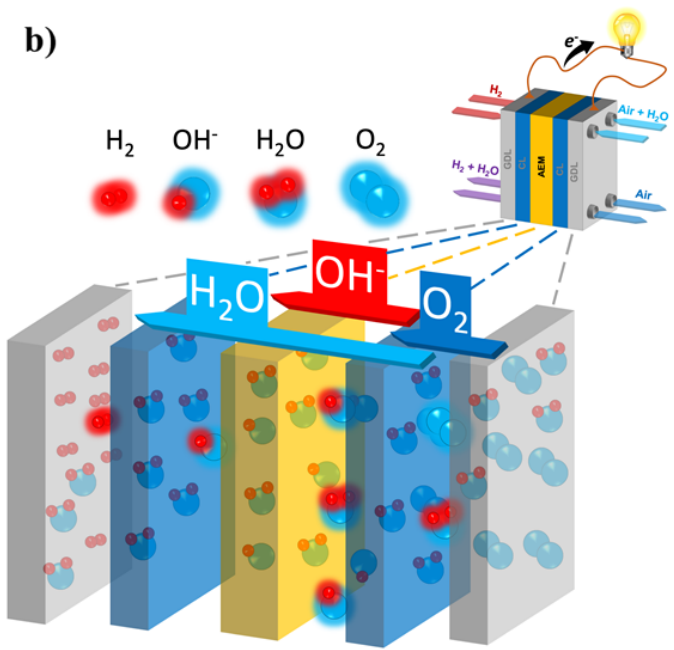

Furthermore, radiation-induced grafting can be carried out by two different procedures: simultaneous irradiation in which irradiation is carried along with the addition of monomers, or pre-irradiation in which the first irradiation of base polymer and then the addition of monomers are performed (Figure 4). Pre-irradiation can be done in a vacuum (trapped radicals are the main reaction sites) or in the air (hydroperoxides are the main reaction sites).

Radiation-induced grafting is a promising method due to its lower cost of production, fine control on the grafting reaction parameters and membrane content, and facile synthesis procedure. Another advantage of radiation grafting is its lower reaction temperature in comparison with normal polymerization reactions. Moreover, an initiator or catalyst is not required to initiate the graft polymerization. Additionally, the grafting process is independent of polymer shape or form. It can easily be applied to any form of the polymer. Moreover, for the membrane applications, starting with a polymer film facilitates obtaining the product in a sheet form. Besides these, a variety of monomers and polymer substrates can be used to obtain the desired structure with various functionalities. 


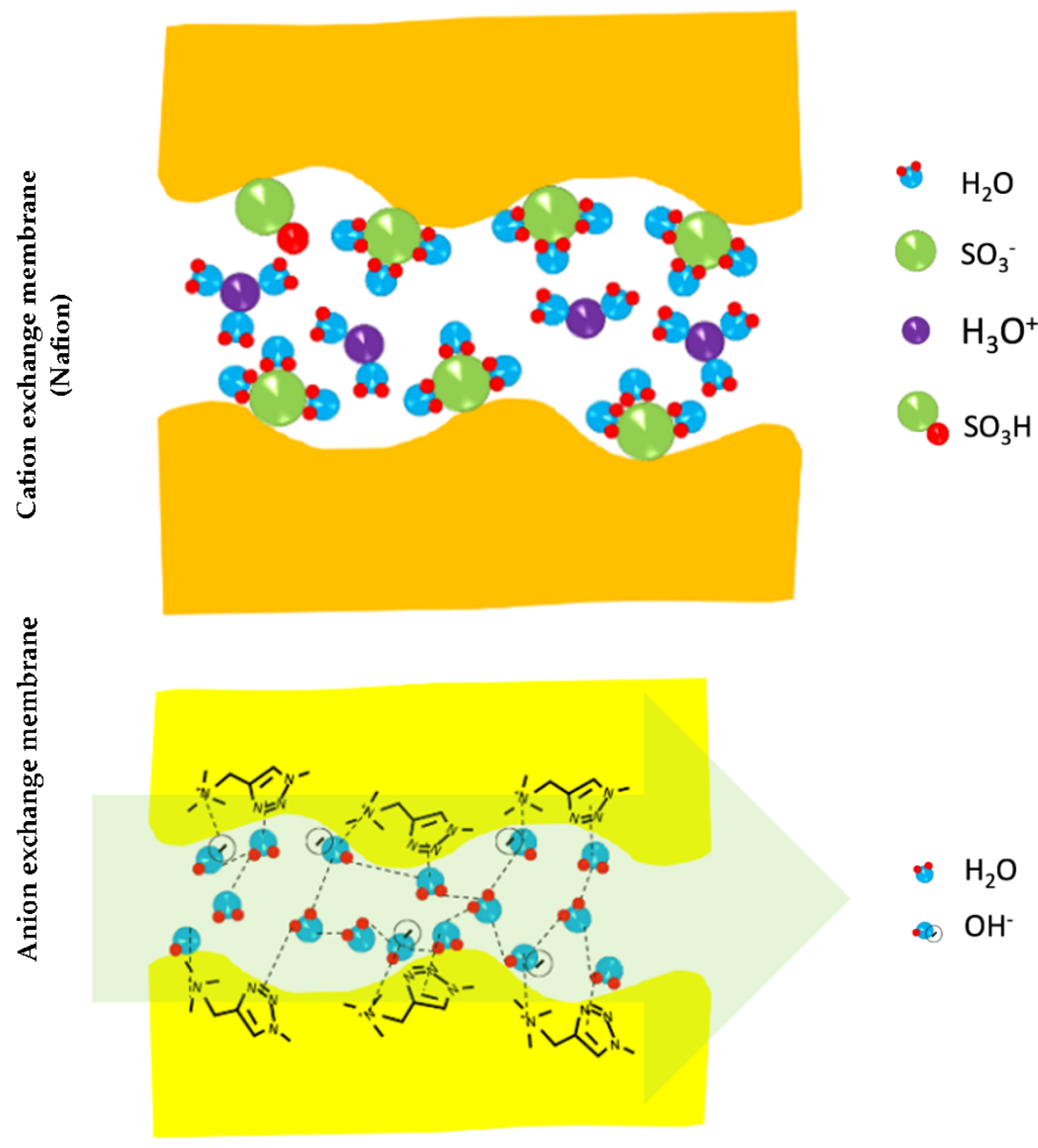

Figure 2. Schematics of a cation exchange (or polymer electrolyte) membrane (PEM) and an anion exchange (or alkaline) membrane (AEM).

There are several examples of commercial radiationgrafted polymer membranes as listed in Table 1 . These commercial membranes depicted relatively lower stability in fuel cell conditions. Thus there is still room for the improvement of radiation-grafted membranes and there are huge research efforts to develop highperformance polymer membranes by radiation grafting.

\section{Proton Exchange Membranes (PEM)}

\subsection{PEM for Low-Temperature Fuel Cells (LT-PEMFC)}

Polymer electrolyte membrane (PEM) plays a central role in fuel cells (PEMFC). It acts as a separator between anode and cathode, avoids direct mixing of hydrogen and oxygen gases, conducts only protons, and prevents electrons from being short-circuited inside the fuel cells [7]. However, to qualify as a good membrane for PEMFC, it needs to have certain properties such as high proton conductivity, low fuel crossover, longer chemical endurance, and higher mechanical strength to sustain in the harsh environment inside the PEMFC [7-9]. One of such membranes available commercially is known as Nafion', made by Du Pont, USA, based upon perfluorosulphonic acid (PFSA) polymeric material. The fluorine-based polymer backbone gives this membrane the mecha- 


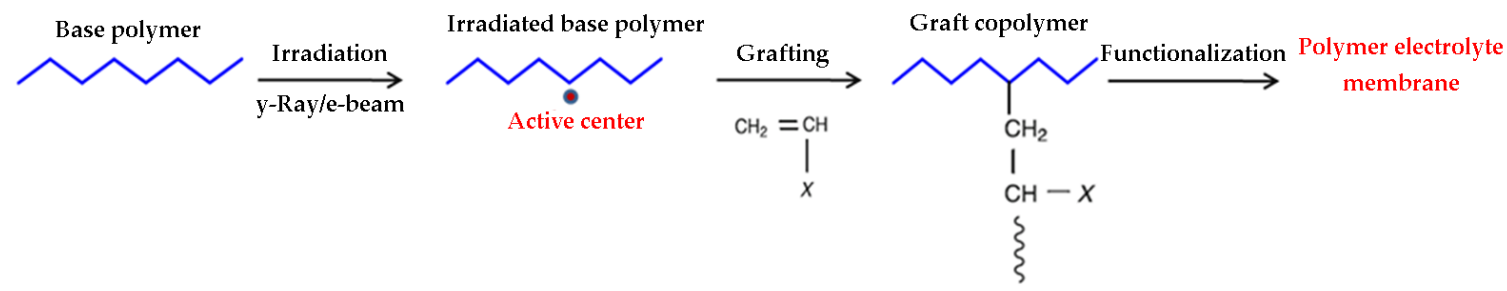

Figure 3. Schematic of radiation-induced grafting for polymer electrolyte membrane preparation.

nical, thermal, and chemical stability for long hours of operation even greater than 60,000 hours while the hydrophobic sulphonic acid functional groups impart the high proton conduction of roughly $0.13 \mathrm{~S} \mathrm{~cm}^{-1}$ at $75^{\circ} \mathrm{C}[7,10-12]$.

Nafion has certain limitations such as it constantly needs to be hydrated and, as well as, the temperature should not exceed $80^{\circ} \mathrm{C}$ since Nafion ${ }^{\circ}$ degrades above 80 ${ }^{\circ} \mathrm{C}$. If these conditions are not met, the membrane dries out, the structure is compromised, and the proton conductivity deteriorates significantly. In addition to this, Nafion is an expensive membrane since it involves fluorine chemistry which has its own synthesis difficulties. To overcome the issue of the cost of Nafion and its aforementioned limitations, alternative techniques have been explored for the synthesis of PEM lowtemperature fuel cells. Radiation-induced grafting and subsequent sulfonation have been extensively employed in this regard (Figure 5).
A balance has to be made in materials selection and reaction parameters in order to obtain the right set of properties for proton exchange membranes for fuel cells. For example, to achieve lower ohmic resistance, thinner membranes are more suitable. However, this can adversely affect the mechanical strength due to the pressure difference of the reactant gases, humidity, and temperature gradient. Similarly, achieving a membrane that is chemically durable for longer cycles can increase the cost of production. These properties can be broadly classified into five categories as summarized below in Figure 6. $[9,13,14]$.

Certain reaction parameters are essential in controlling and optimizing the degree of grafting and grafting distribution to get the desired structure and properties of the graft copolymer membranes for fuel cells. The choice of materials such as monomers, crosslinkers, and polymer substrates dictates the cost and stability of the
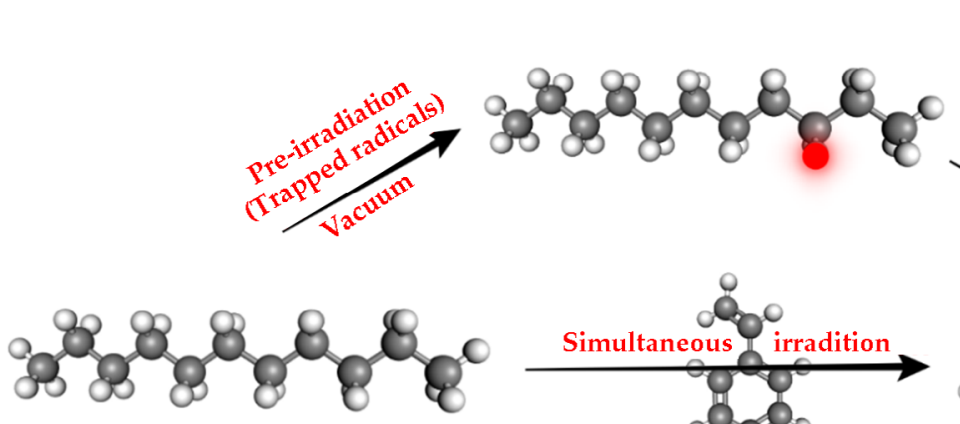

Polymer backbone
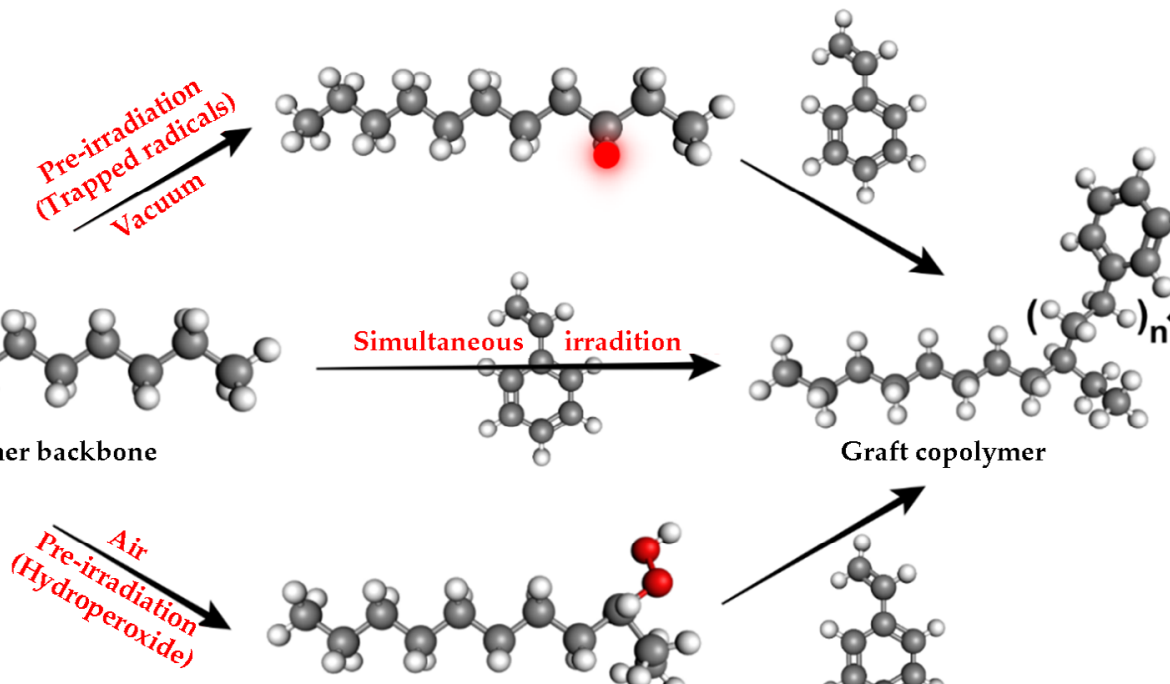

Graft copolymer

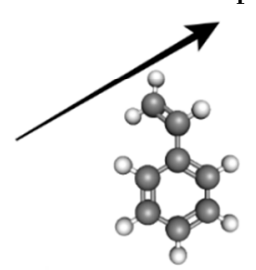

Figure 4. Demonstration of different radiation-induced grafting procedures. 
Table 1. List of commercial radiation-grafted ion-exchange membranes [6]. Reproduced with permission from Elsevier Ltd.

\begin{tabular}{|c|c|c|c|}
\hline Company & Commercial name & Product & Origin \\
\hline - United technology & - & -Fibrous ion exchange sheets & Japan \\
\hline -Ebara Research Co., Ltd. & - & Sulfonic acid non-woven fabric & Japan \\
\hline $\begin{array}{l}\text {-Pall Gellman Sci. Inc. } \\
\text { - RAI Research Corp }\end{array}$ & $\begin{array}{l}\text { PERMION } \\
\text { R4010, R1010, } \\
\text { and R4035 }\end{array}$ & $\begin{array}{l}\text { - Sulfonated polystyrene/PTFE } \\
\text { - Cation exchange membranes }\end{array}$ & USA \\
\hline -Solvay & $\begin{array}{c}\text { R5010 } \\
\text { CRA } \\
\text { Morgan CDS } \\
\text { Morgan ADP 100-2 }\end{array}$ & $\begin{array}{l}\text { Styrene/PE } \\
\text { - Cation exchange membrane } \\
\text { - Cation exchange membrane } \\
\text { - Anion exchange membrane }\end{array}$ & $\begin{array}{l}\text { USA } \\
\text { Belgium }\end{array}$ \\
\hline - Ashahi Glass Inc. & - Flemion & - Cation exchange membrane & Japan \\
\hline $\begin{array}{l}\text { Shanghai Shilong Hi-Techn. } \\
\text { Corp. Ltd. } \\
\text { - CEC, Japan }\end{array}$ & RAYMION & $\begin{array}{c}\text {-Sulfonic acid non-woven fabric } \\
\text { - Sulfonated } \\
\text { polytrifluorostyrene/ETFE }\end{array}$ & $\begin{array}{l}\text { China } \\
\text { Japan }\end{array}$ \\
\hline
\end{tabular}

end product membranes. These reaction parameters are summarized below in Figure 7. [13,15-17]. The effect of these reaction parameters and materials choice will be discussed briefly, followed by some examples of radiation grafted membranes application in PEMFC in literature.
Utilizing high energy radiation such as X-rays, gamma rays, or electron beam, is an efficient way to graft polymers. The high energy photons can penetrate deep into the matrix, allowing grafting throughout the material. By controlling the radiation dose, the degree of grafting can be easily managed. Poly(tetrafluoroethylene) (PTFE) can experience serious degradation even after modera-

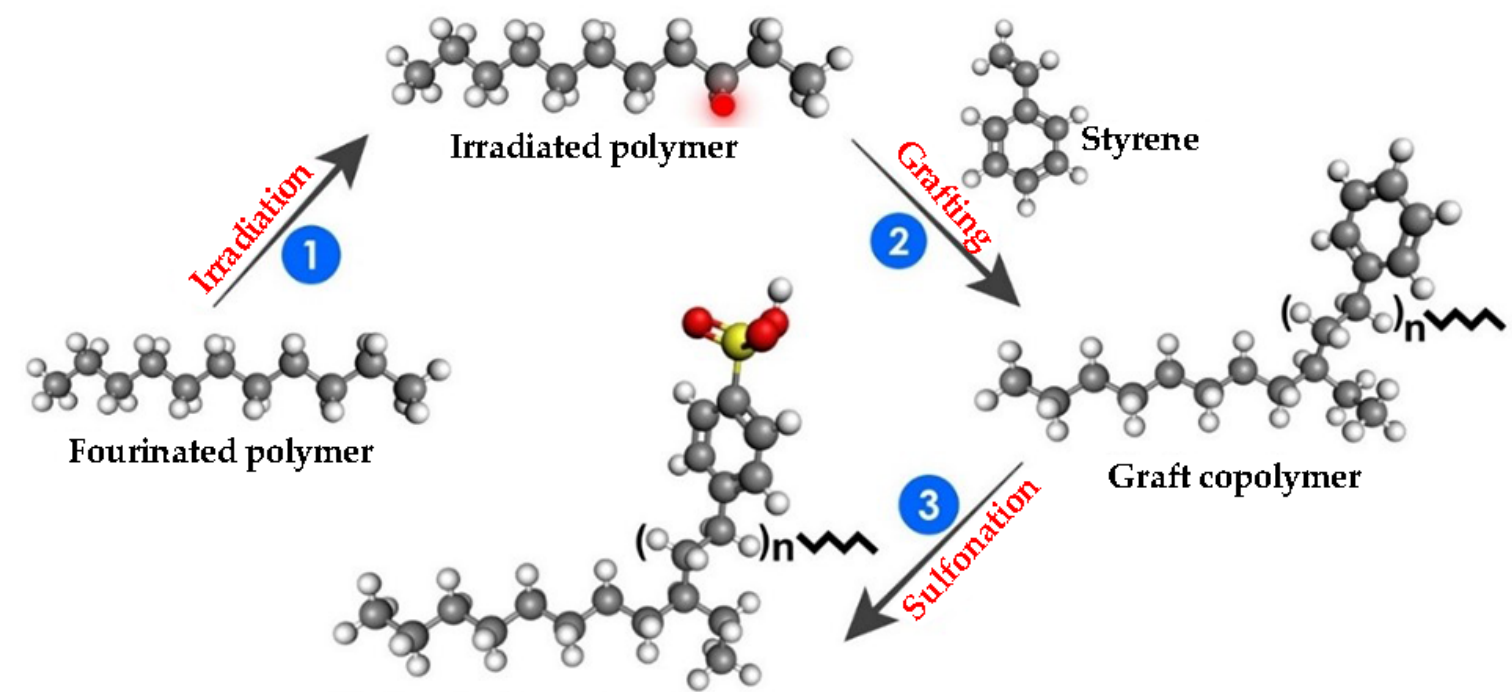

Proton exchange membrane

Figure 5. Radiation grafting process for the synthesis of membranes for PEMFC. 


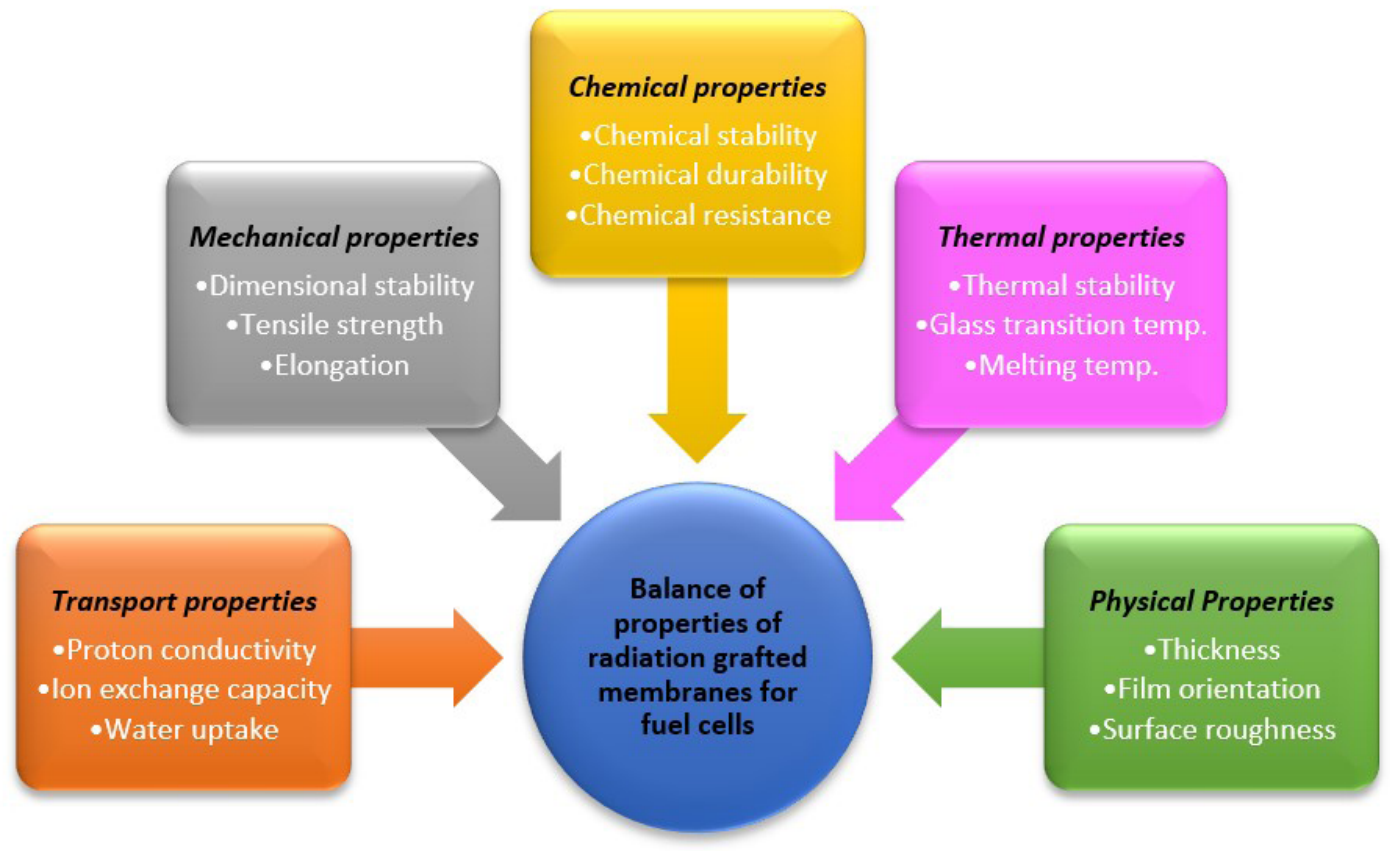

Figure 6. Balance of properties of radiation grafted membranes for PEMFC.
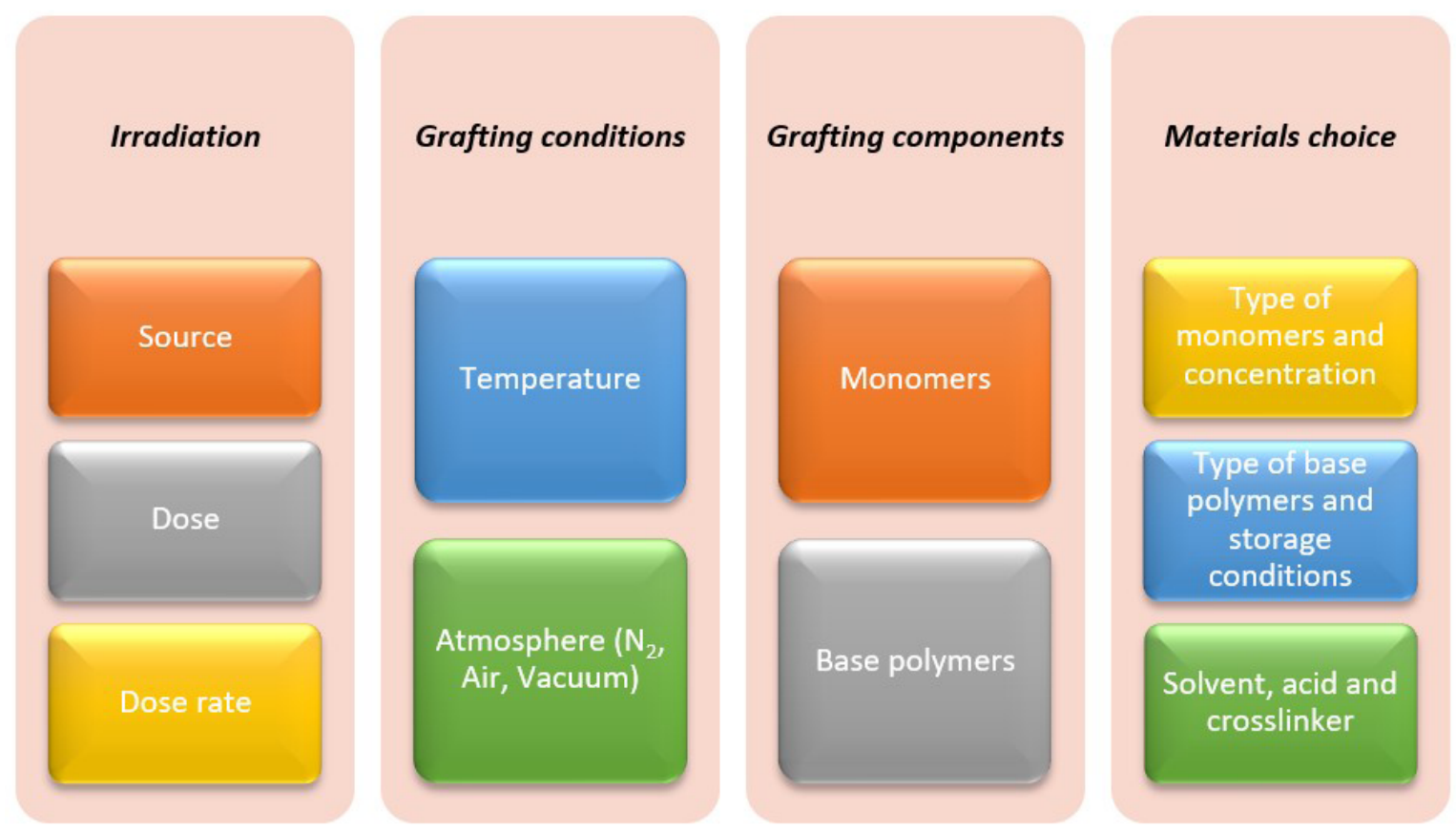

Figure 7. Reaction parameters and materials choice for radiation grafted membranes for PEMFC. 
te irradiation [18]. After irradiation, acid fluoride (-COF) groups form, and then hydrolyze into carboxyl groups $(-\mathrm{COOH})$ when exposed to humid air $[19,20]$. For that reason, the $-\mathrm{COOH}$ amount increases with the irradiation dosage [21]. The polymer degradation happens due to the creation of chain-end radicals $\left(-\mathrm{CF}_{2}-\mathrm{CF}_{2}\right)$ or chain alkyl radicals $\left(-\mathrm{CF}_{2}-\cdot \mathrm{CF}-\mathrm{CF}_{2}-\right)$. This leads to a decline in the thermal stability of the irradiated polymer [22] The temperature also affects the type of radicals. When poly(tetrafluoroethylene-co-hexafluoropropylene) (FEP) is irradiated at low temperatures, the major radical moiety is a chain scission type. However, at room temperature, chain-end radicals start to dominate [23]. In addition to that, with increasing temperature, the radical concentration also increases.

There is a significant variation in the degradation behavior of PTFE, FEP, and poly(tetrafluoroethylene-coperfluoro vinyl ether) (PFA) under irradiation [24,25]. While FEP has a pendant group of $-\mathrm{CF}_{3}$, PFA contains $-\mathrm{OC}_{3} \mathrm{~F}_{7}$ group. These groups create amorphous regions in polymer and facilitate radical mobility. This results in more chain scission radicals than PTFE. Since the mobility in PTFE is lower, radical-radical recombination becomes harder; thus, PTFE becomes more sensitive to irradiation. After irradiation on PFA and FEP, more radicals are formed. These radicals eventually transform into carboxyl groups with FEP having the highest and PTFE having the lowest amount [26].

Fluoropolymers are extensively employed as the base polymers for radiation-induced grafting because of their excellent thermal and chemical stability and good mechanical properties (Figure 8). The base polymer selected for the grafting is especially crucial since, after irradiation, substantial changes can occur on it and it can directly impact the grafting amount $[27,28]$. For example, under the same conditions, PTFE, FEP, PVDF, and ETFE reaches a grafting amount of 5, 28, 56, and $62 \%$, respectively. The variance of grafting amount is probably due to the change in radical concentration, radical types, and degrees of crystallinity. The polymers with higher crystallinity result in the lesser radical formation and lower monomer penetration, thus lesser grafting amount. Grafting performed above the glass transition temperature $\left(T_{g}\right)$ has a negative effect on the overall process. Above $T_{g}$, the mobility of the chains increases the recombination of the chains and decreases the amount of grafting [28]. ETFE chains have more radicals since $\mathrm{C}-\mathrm{H}$ bond strength is lower than that of C-F or C-C bonds $[29,30]$. The molecular weight of the base polymer also affects the amount of grafting. With a higher molecular weight, the grafting amount decreases. Interestingly with acrylic acid in thinner films, a higher dosage is needed to reach a similar grafting amount. The chain orientation in thin films obstructs the permeability $[27,31,32]$. Conversely, other studies did not observe a relation of thickness to grafting amount [33]. The storage of irradiated films before grafting is an important issue. It has been reported that fluorinated polymers keep their ability to graft for long periods $[34,35]$. The irradiated PVDF and ETFE films keep their activities for more than a year below the storage temperature of $-18^{\circ} \mathrm{C}$. On the other hand, irradiated FEP films keep their grafting ability even after 118 days when stored at $-60^{\circ} \mathrm{C}$. [35].

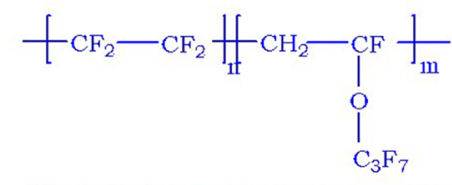

Poly (tetrafluoroethylene-co-perfluoropropyl vinyl ether) (PFA)

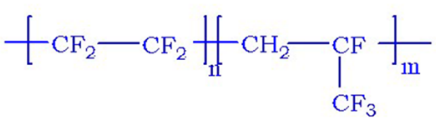

Poly(tetrafluoroethylene-co-hexafluoropropylene) (FEP)

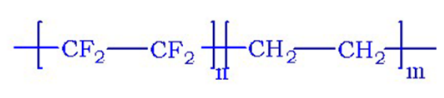

Poly(ethylene-alt-tetrafluoroetylene) (ETFE)

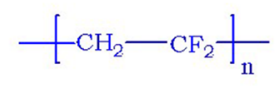

Poly(Vinylidine fluoride) (PVDF)

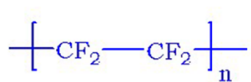

Poly(tetrafluoroethylene) (PTFE)

Figure 8. Base polymers used for the preparation of PEM [6]. Reproduced with permission from Elsevier Ltd. 
There are various monomers such as vinyl, styrene, TFS, PFS, AMS, MAN, etc. that can be employed for grafting on polymer substrates via radiation grafting (Figure 9). One such example is vinyl monomer that has been extensively used in radiation grafting reactions. Besides that, styrene monomers became more popular for radiation-induced grafted membranes for use in PEMFC [36]. This is because of the low cost and ability to modify the benzene ring of the grafted styrene with different functionalities by electrophilic substitution reactions. For example, the sulfonic acid group can be interchanged with the end of the styrene group for reasonable conductivity. The concentration of the monomer is the most significant parameter affecting the grafting. At high concentrations, radicals go deep in the structure can be accessed more efficiently, thus with increasing concentrations, the grafting amount also increases $[35,37]$. However, at higher concentrations, excessive homo-polymerizations can obstruct monomer diffusion into the material. For example, this kind of behavior leads to a maximum point at a certain styrene concentration for PTFE films [38]. For styrene grafting into ETFE, this maximum concentration was reported at $20 \%(\mathrm{v} / \mathrm{v})$. It should be noted that similar behavior was also reported for styrene grafting into PTFE, FEP, and PFA films [39-41].

Crosslinkers are used together with the monomers to obtain additional properties in the membrane. One of the main aims is to improve the stability in the fuel cells $[35,42]$. Especially swelling during fuel cell operation can be reduced by crosslinking. Depending on the crosslinker concentration, the grafting amount can vary. At lower concentrations, since it increases branching, grafting also increases. However, at higher concentrations because of high crosslinking at the surface, diffusion is limited; thus, grafting decreases $[43,44]$. Although the membrane's stability can be increased with crosslinking, this process makes the membrane denser and less proton conductive [45-47].

In the first steps of the radiation grafting process, the grafting occurs at the polymer film surface. After that, the film starts to swell in the solvent, and grafting continues into the material with the monomers' diffusion [37,48-50]. The solvent used should create a suitable environment for monomer diffusion, meanwhile, it should also swell the polymer. Due to the slow monomer diffusion into the polymer, only surface grafting happens with poor swelling solvents.

On the other hand, when solvents properly swell the polymer, a homogenous grafting occurs. Methanol, ethanol, propanol, toluene, benzene, dichloromethane are some of the solvents used for styrene and its derivatives' grafting. The polarity and the chain transfer constant of the solvent affect graft penetration. For example, dichloromethane as the solvent yields a higher grafting amount than methanol and benzene [49]. The radical yield for benzene is higher than methanol and cyclohexane for a styrene solution since its solubility parameter is much closer [51]. Some polymers like PTFE do not swell enough in standard solvents. In these cases, aqueous mixtures are utilized. For methacrylic<smiles>C=CC(=O)OC</smiles>

Methyl acrylate<smiles>C=Cc1ccccc1C</smiles>

2-Methylstyrene<smiles>C=Cc1ccc(C)cc1</smiles>

4-Methylstyrene<smiles>C=Cc1ccc(C(C)(C)C)cc1</smiles>

4-tert-Butylstyrene<smiles>C=Cc1ccc(CCl)cc1</smiles>

4-Vinylbenzyl chloride

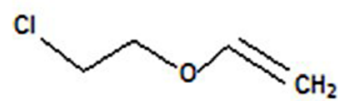

2-Chloroethylvinyl ether

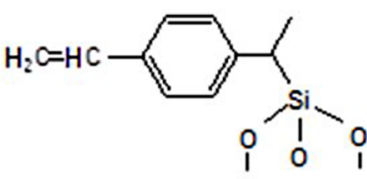

1-(4-Styryl)ethyltrimethoxysilane

Figure 9. Alternative monomers used for the preparation of PEM [6]. Reproduced with permission from Elsevier Ltd. 


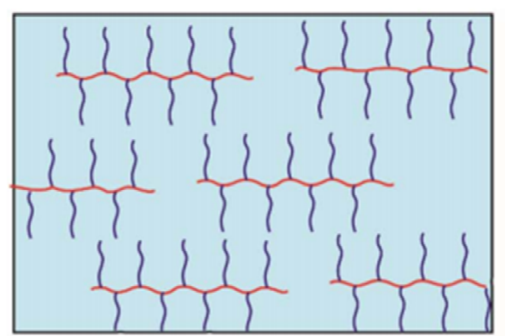

a) PVDF-g-PSSS in DMSO

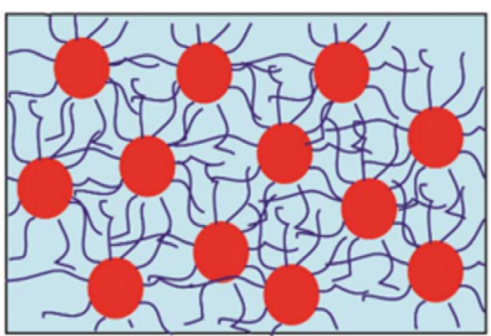

b) Polymer phase separation

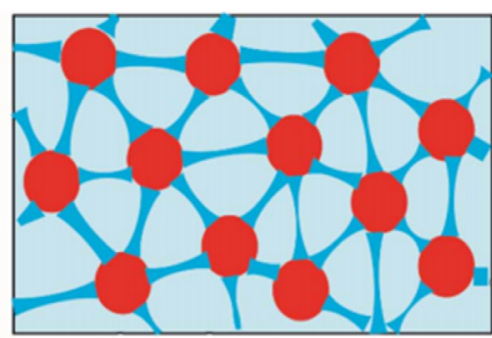

c) Hydrophilic network formation

Figure 10. PVDF-g-PSSS radiation-induced grafted membrane for PEM fuel cells [58]. Reproduced with permission from Elsevier Ltd.

acid grafting into PTFE, methanol/water mixture $(30 / 70$ wt.\%) results in the best swelling [52]. For an FEP/styrene system, water/isopropanol yields high grafting amounts [39].

For fuel cell applications, the styrene grafted films should also be sulfonated to achieve proton conduction. During this reaction, sulfonic acid groups are added to the aromatic ring. The addition of sulfonic acid groups can be achieved by various compounds like sulphuric acid, sulfur trioxide, sulphonyl chloride, acetyl sulfate, and chlorosulphonic acid. It was reported that the sulfonation rate increases with short sulfonation durations [18]. For longer exposures, the hydrophilicity controls the amount of sulfonation. The amount of sulfonic acid groups increases with the grafting level. Nevertheless, for an efficient sulfonation, the film should have a grafting throughout the thickness [53].

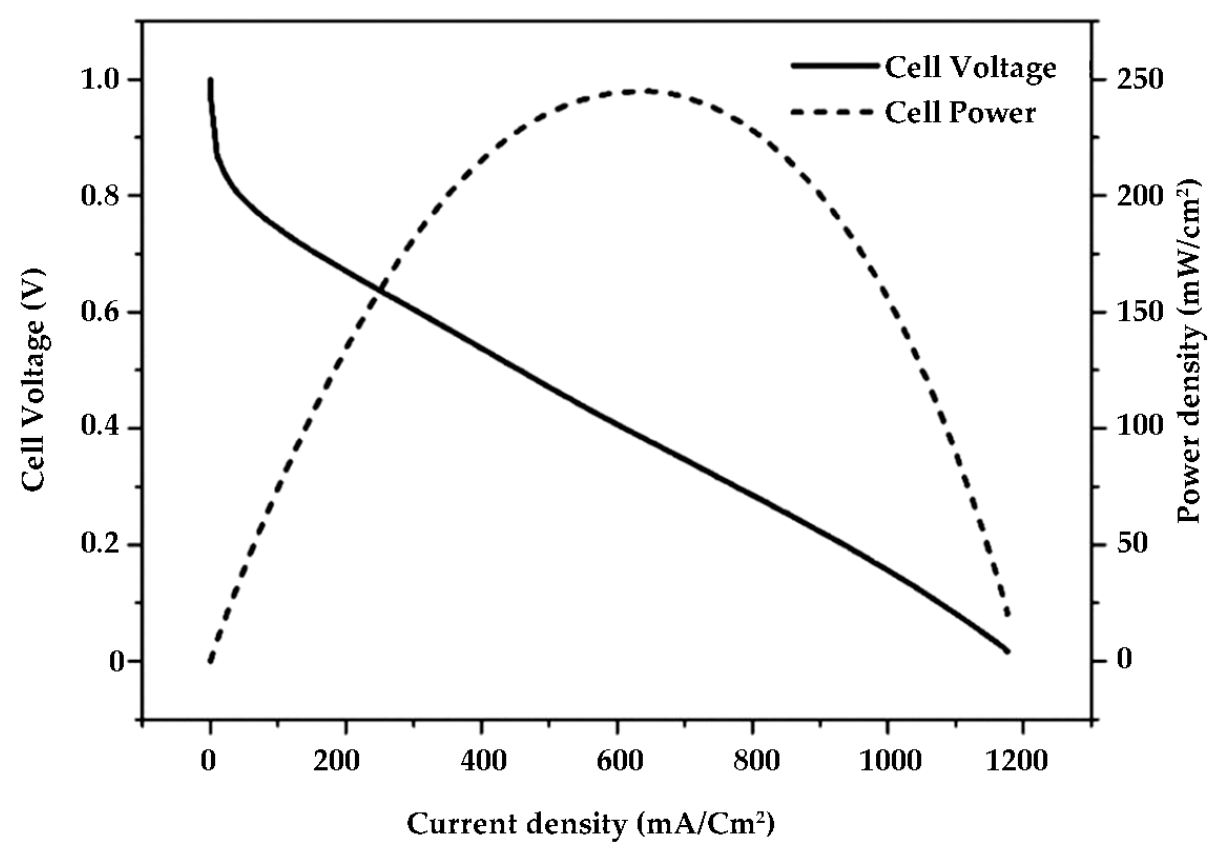

Figure 11. PEMFC performance curves of PVDF-g-PSSA membrane (35\% graft level at $60^{\circ} \mathrm{C}$ and $80 \% \mathrm{RH}$ ) [58]. Reproduced with permission from Elsevier Ltd. 
One example of a fluoropolymer in the radiation grafted membrane is FEP for fuel cells. However, FEP undergoes damage under irradiation as discussed earlier. To replace FEP, ETFE is used which has better mechanical properties due to the ability against crosslinking. $L$. Gubler et al. prepared a wide range of pre-irradiation grafting of styrene/DVB based ETFE membranes with varying grafting levels from $2.3 \%$ to $69 \%$ and found that the optimum grafting level was between $20 \%$ to $30 \%$. The fuel cell performance test revealed a result comparable to the Nafion membrane with good durability of about 770 hours with no degradation [54].

In another study of radiation grafted membrane, the effect of varying degrees of crosslinking DVB as a comonomer to styrene, grafted on ETFE was studied. It was found that a high degree of crosslinking makes the membranes brittle and limits the proton conductivity. Good fuel cell performance was obtained at the ratio of 95:5 for styrene: DVB monomer (overall grafting level of 25\%) and it showed comparable results to Nafion ${ }^{\circ} 112$ membranes for over 2000 hours under $\mathrm{H}_{2} / \mathrm{O}_{2}$ atmosphere and $80^{\circ} \mathrm{C}[55,56]$. PTFE is another example of fluoropolymers that exhibits good chemical and electrical properties but upon small irradiation doses, it undergoes loss in its molecular weight and mechanical properties [43] and thus cannot be used in membranes. To overcome this issue, the application of crosslinked PTFE polymer substrates showed significant improvement in radiation resistance [31].

One such example is radiation-induced co-grafting of styrene and BVPE crosslinkers into radiation crosslinked PTFE film. The low-temperature fuel cell performance test showed comparable results with Nafion 112 membrane and showed better results than withoutcrosslinking due to its better membrane-electrode interface, increased membrane durability, and chemical stability [57].

Table 2. Summary of radiation grafted membranes for LT-PEMFC with different properties, fuel cell performance, and durability.

\begin{tabular}{|c|c|c|c|c|c|c|c|}
\hline $\begin{array}{c}\text { Base Polymer and } \\
\text { Monomer }\end{array}$ & $\begin{array}{c}\text { Degree of } \\
\text { grafting }\end{array}$ & $\begin{array}{l}\text { Conductivity } \\
{\left[\mathrm{mS} \mathrm{cm}^{-1}\right]}\end{array}$ & $\begin{array}{l}\text { Ion exchange } \\
\text { Capacity } \\
\text { [mmol/g] }\end{array}$ & $\begin{array}{c}\text { Current den- } \\
\text { sity at } 0.6 \mathrm{~V} \\
{\left[\mathrm{~mA} \mathrm{~cm}^{-2}\right]}\end{array}$ & $\begin{array}{l}\text { FC Test Condi- } \\
\text { tions (Temp, } \\
\text { Humidity, gas } \\
\text { ratio) }\end{array}$ & $\begin{array}{l}\text { FC Durability } \\
\text { Conditions }\end{array}$ & $\begin{array}{l}\text { Base Poly- } \\
\text { mer and } \\
\text { Monomer }\end{array}$ \\
\hline $\begin{array}{c}\text { Nafion }^{\circledR} 112 \\
\text { membrane (given } \\
\text { as standard) }\end{array}$ & - & 83 & 0.9 & 800 & $\begin{array}{c}65^{\circ} \mathrm{C}, 100 \% \\
\mathrm{RH}, \mathrm{H}_{2} / \mathrm{air} \\
(80: 60)\end{array}$ & $\begin{array}{c}>2500 \mathrm{~h}, 0 . \mathrm{A} \\
\mathrm{cm}^{-2}\end{array}$ & {$[67]$} \\
\hline $\begin{array}{c}\text { ETFE-g- } \\
\text { Styrene/5\% DVB }\end{array}$ & $25.8 \%$ & 62 & - & 950 & $\begin{array}{c}80^{\circ} \mathrm{C}, 100 \% \\
\mathrm{RH}, \mathrm{H}_{2} / \mathrm{O}_{2} \\
(1.5 / 1.5)\end{array}$ & $\begin{array}{c}2180 \mathrm{~h}, 0.5 \mathrm{~A} \\
\mathrm{~cm}^{-2}\end{array}$ & {$[55,56]$} \\
\hline $\begin{array}{c}\text { FEP-g- } \\
\text { Styrene/10\% DVB }\end{array}$ & $18.2 \%$ & 41 & - & 900 & $\begin{array}{c}80^{\circ} \mathrm{C}, 100 \% \\
\mathrm{RH}, \mathrm{H}_{2} / \mathrm{O}_{2} \\
(1.5 / 1.5)\end{array}$ & - & {$[55,56]$} \\
\hline $\begin{array}{l}\text { ETFE-g-TFS } \\
\text { derivative }\end{array}$ & $225 \%$ & 300 & 2.15 & 900 & $\begin{array}{c}60^{\circ} \mathrm{C}, 100 \% \\
\mathrm{RH}, \mathrm{H}_{2} / \mathrm{O}_{2} \\
(1.5 / 9.5)\end{array}$ & $524 \mathrm{~h},-$ & [61] \\
\hline $\begin{array}{c}\text { cPTFE-g-Styrene/ } \\
\text { BVPE }\end{array}$ & $24 \%$ & 84 & 1.6 & 850 & $\begin{array}{c}80^{\circ} \mathrm{C}, 100 \% \\
\mathrm{RH}, \mathrm{H}_{2} / \mathrm{O}_{2} \\
(1.5 / 1.5)\end{array}$ & $\begin{array}{c}>500 \mathrm{~h}, 0.5 \mathrm{~A} \\
\mathrm{~cm}^{-2}\end{array}$ & [57] \\
\hline $\begin{array}{c}\text { ETFE-g-Styrene/ } \\
\text { MAN }\end{array}$ & $27.4 \%$ & 69 & 1.35 & - & $\begin{array}{c}80^{\circ} \mathrm{C}, 100 \% \\
\mathrm{RH}, \mathrm{H}_{2} / \mathrm{O}_{2} \\
(1.5 / 1.5)\end{array}$ & $\begin{array}{c}>1032 \mathrm{~h}, 0.5 \\
\mathrm{~A} \mathrm{~cm}^{-2}\end{array}$ & [62] \\
\hline $\begin{array}{c}\text { Microstructured } \\
\text { ETFE-g- } \\
\text { Styrene/5\%DVB }\end{array}$ & $35 \%$ & 70 & - & 800 & $\begin{array}{c}80^{\circ} \mathrm{C}, 100 \% \\
\mathrm{RH}, \mathrm{H}_{2} / \mathrm{O}_{2} \\
(1.5 / 1.5)\end{array}$ & $\begin{array}{c}580 \mathrm{~h}, 0.5 \mathrm{~A} \\
\mathrm{~cm}^{-2}\end{array}$ & {$[66]$} \\
\hline PVDF-g-PSSA & $35 \%$ & 70 & - & 650 at $0.4 \mathrm{~V}$ & $\begin{array}{c}60^{\circ} \mathrm{C}, 80 \% \mathrm{RH}, \\
\mathrm{H}_{2} / \mathrm{O}_{2}\end{array}$ & - & [58] \\
\hline
\end{tabular}


The use of PVDF polymer substrate, especially in powder form provides more active sites induced by irradiation for the incoming monomers, resulting in better penetration and homogeneous distribution of grafting. An interesting example by Sadeghi et al. is a single step irradiation and grafting of SSS to PVDF powder with up to $35 \%$ grafting level. In this study, they processed the solution by tape casting using a doctor blade to achieve a uniform membrane with a sub-micron structure (Figure 10). Not only they attained enhanced proton conductivity $\left(70 \mathrm{mS} \mathrm{cm}^{-1}\right)$ but also good mechanical properties. They showed the power density of $250 \mathrm{mWcm}^{-2}$ in fuel cell performance test (Figure 11) [58].

A drawback of styrene is when it is grafted and sulfonated, it degrades in the fuel cell's harsh environment, probably due to the radicals such as hydroperoxy and hydroxy which attack the hydrogen in the vinyl part $[59,60]$ resulting in a quick degradation of fuel cell performance. Therefore, a more stable monomer than styrene is TFS which again has some drawbacks such as hard and dangerous synthesis process, lower polymerization kinetics, irreversible dimerization, and sulfonation issues.

To address the above issue of TFS, a novel derivative of TFS was synthesized with a sulfonic acid group attached to the para-position of the aromatic benzene at the end of $-\mathrm{CF}_{2}-\mathrm{CF}_{2}$ - bridge [61]. Subsequently, this monomer with the sulfonic acid group was grafted on the ETFE polymer substrate via irradiation. The fuel cell performance revealed better results than Nafion 112 but durable less than Nafion ${ }^{\circ} 112$.

As can be seen in Table 2, alternative membranes suffer from some durability issues. Although they have comparable beginning of life (BOL) fuel cell performance, long term cycling is not good. One such study to improve upon the cycling life of membranes was performed by a novel approach using co-grafting MAN with uncrosslinked styrene through radiation grafting onto the ETFE base polymer. This scheme increased the intrinsic oxidative stability of the uncrosslinked membrane. Incorporating MAN into the structure improved the chemical stability with over 1000 hours of fuel cell operation without any appreciable loss in performance [62].

DVB is a crosslinker monomer that is used with styrene in the radiation grafting method to improve the oxidative stability of the proton exchange membrane of fuel cells. This helps with the properties needed in fuel cells like thermal stability, water uptake, proton conduction, fuel cell performance, and durability [45,63-65]. However, there is an optimum level of DVB concentration that can be used, after which the aforementioned properties such as water uptake, ion exchange capacity, and proton conductivity start to decrease (Table 1) $[55,66]$. A ratio of 95:5 for styrene; DVB grafted on ETFE films via irradiation, was observed to work best for fuel cell performance. Beyond 5\% DVB concentration, the ohmic resistance increases and the membrane becomes brittle. On the other hand, lower concentrations of DVB results in poor membrane-electrode connections, and the fuel cell performance decreases [55].

Engineering the membrane through varying the synthesis conditions result in changing the properties of the membrane. It was previously reported that there is a positive correlation between the degree of grafting and the ion exchange capacity $[68,69]$. The grafting moieties hold the required functional groups emulsifying the passage of protons. Therefore, it is expected for the capacity to increase by introducing more functional groups accompanied by higher grafting.

Another correlation occurs between the degree of grafting and the conductivity of the membrane through the amount of water uptake. It is expected that the water content of the membrane to have a significant effect on its conductivity. This is due to the fact that the protons are transported by interacting with the water molecules present in the system [70]. With the introduction of additional functional groups through increasing the degree of grafting, one can craft a membrane with certain hydrophilicity which in turn boosts the water uptake of the membrane $[35,71,72]$.

As a result, the conductivity of radiation grafted polymer membranes can be optimized through the grafting process of the polymer. Radiation grafted polymer membranes are expected to perform optimally under fully humidified conditions. However, operation under partially humidified conditions is favorable since it brings a sort of condition flexibility during operation. The superiority of the grafted polymer membrane's conductivity as compared to Nafion ${ }^{\circ}$ was shown previously. However, the conductivity drops drastically as the relative humidity is shifted towards lower partial humidified conditions. This drop can be attributed to the poor distinction between the polymer backbones and the proton-conducting pathways, lower percolati- 
on of the hydrophilic domains, and higher pKa values compared to Nafion resulting in higher localization of the protons [73].

The fuel cell performance of the radiation grafted membranes (FEP-25 sample which has an 18\% degree of grafting and $10 \%$ crosslinker ratio) was compared with Nafion 112 as the reference sample. The two polymerization curves are similar with minor differences in their ohmic resistance which is lower for that of the grafted polymer. This shows a promising behavior of the grafted polymer membrane as it possesses similar performance as that of Nafion based membranes with even good lifetime exceeding 4000 hours at $80^{\circ} \mathrm{C}$ cell temperature [74].

\subsection{PEM for High-Temperature Fuel Cells (HT- PEMFC)}

As discussed in previous sections, several challenges remain in developing PEMFCs that should be addressed before they could meet the commercialization criteria for instance they have high-cost catalysts, complex water management, sluggish oxygen reduction reaction, and low durability of the membrane electrode assembly (MEA) [6]. In this regard, HT-PMFCs have gained a tremendous amount of attention due to their potential and structure. Most of the shortcomings in PEMFCs originate from their lack of ability to operate at temperatures above $100^{\circ} \mathrm{C}$ and the fact that the current perfluorosulfonic ionomers such as Nafion operate based on water-assisted conduction [75]. The inevitable water requirement limits the operating temperature to below $100^{\circ} \mathrm{C}$. In HT-PMFCs, using inorganic acid-based membranes enables the operating temperatures up to $100-200^{\circ} \mathrm{C}$. The status of conductivity of various membranes based on their operating temperature range, reveals that Nafion and polybenzimidazole/phosphoric acid (PBI/PA) membranes are considered as the most promising candidates for low and high-temperature PEMFCs with reliable performance at a temperature below $80^{\circ} \mathrm{C}$ and above $130^{\circ} \mathrm{C}$, respectively. However, investigating a new generation of membranes for the operating at $80-150^{\circ} \mathrm{C}$ range is ongoing in the literature $[76,77]$.

PEMFCs operation at high temperature offers various advantages such as higher efficiency, elimination of the need for a cooling system, recyclability of the generated heat, and lower catalyst poisoning $[6,78]$. Advantages of high-temperature operation of PEMFC listed below:

\section{Enhancement of reaction kinetics}

Oxygen reduction reaction (ORR) has very sluggish kinetics (about 5 orders of magnitude less than HOR) that needs high loading of expensive catalyst materials to reach reasonable efficiency. Higher operating temperature provides adequate activation energy for electrochemical reactions at both anode and cathode sides in PEMFCs. For this reason, alternative inexpensive catalysts could be utilized instead of platinum. In addition to that, higher temperature causes higher proton conductivity and less voltage loss due to the decrease in mobility resistance of different species such as gases, water, and protons [79].

\section{Lower catalyst poisoning}

Adsorption of $\mathrm{CO}$ on Pt catalysts above $150^{\circ} \mathrm{C}$ thermodynamically is not as favorable as in lower temperatures. Therefore, higher operating temperatures do not necessitate a very high purity of inlet gases and lead to less catalyst contamination $[78,80]$.

\section{Better water management}

The water-free proton conductivity of HT-PMFCs makes it an ideal candidate in terms of water management issues which are; active surface area blockage, back diffusion, water content control in optimized proton conductivity, and flooding at cathode electrode [76$78,80,81]$.

\section{Improved heat management}

In LT-PEMFCs the heat that is generated as a byproduct of electrochemical reactions must be immediately eliminated from the system to prevent degradation of different components. This issue requires an efficient cooling system as an essential part. However, in HTPEMFCs there is no need for such a cooling system, and this makes the structure to be more compact. Furthermore, the generated heat in HT-PEMFCs can be utilized in cogeneration of energy and increases the efficiency $[76,80]$.

The overall solid polymer electrolyte material for fuel cell application can be divided into five distinct categories as illustrated in (Figure 12). Among them, according to their physicochemical properties, membrane development to be used in HT-PEMFCs can be categorized into three groups: i) Modified perflorosulfonated acid (PFSA) membranes, ii) acid-based polymer membranes, and iii) other types of sulfonated polymers and their composites. Acid-based polymer membranes have 


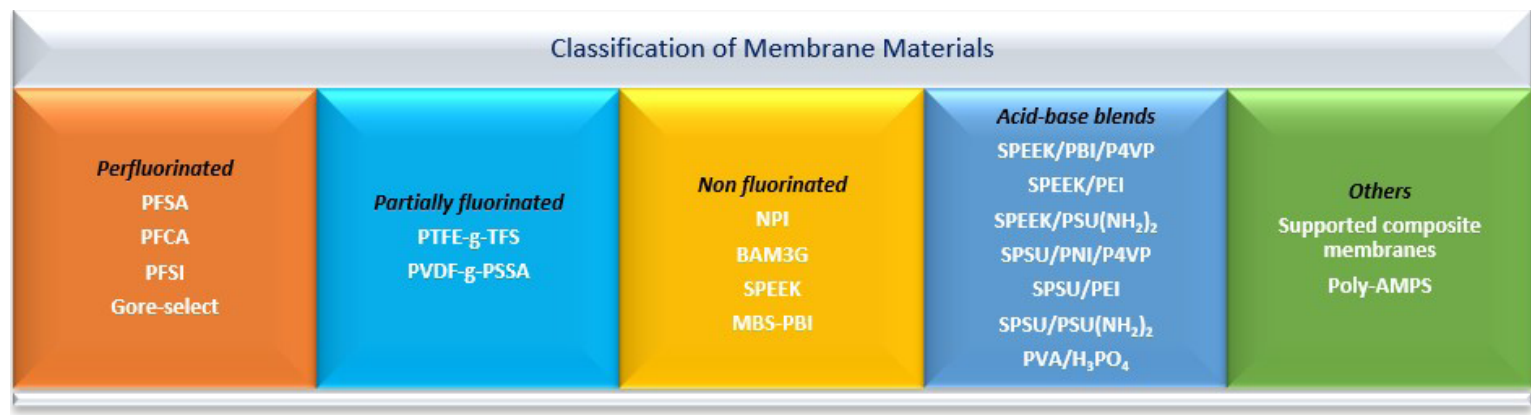

Figure 12. Classification of various membrane materials [82]

been the focus of attention during the past decade. For example, phosphoric acid-doped poly(benzimidazole) (PBI) has been shown to have higher chemical and mechanical stability and also better performance up to $200^{\circ} \mathrm{C}$ without humidity addition [75].

As mentioned above, one of the methods to develop a membrane that could operate at temperatures higher than $80^{\circ} \mathrm{C}$ is sulfonic acid attachment through sulfonation or by polymerization of sulfonated monomers to thermally stable aromatic polymers [6]. There are reports in which sulfonated poly (arylenet hersulfone) (SPES) membrane with $500 \mathrm{~h}$ durability at $100^{\circ} \mathrm{C}$ and sulfonated poly (etheretherketone) (SPEEK) membrane with the durability of $300 \mathrm{~h}$ at above $90^{\circ} \mathrm{C}$ have been investigated [6].

Instead of the sulfonic acid doped membrane, the application of phosphoric acid doped one has gained more attention. However, challenges exist in the synthesis and preparation process and this membrane has not shown a highly efficient and durable performance in high-temperature situations [6].

- There are several proton conduction mechanisms in phosphoric acid doped membranes:

- $\quad$ Proton hopping from $\mathrm{N}$ sites to each other

- $\quad$ Proton hopping from $\mathrm{N}-\mathrm{H}$ site to a phosphoric acid anion (Grotthuss diffusion mechanism)

- Proton hopping along the $\mathrm{H}_{2} \mathrm{PO}_{4}^{-}$anionic side chain

- $\quad$ Proton hopping via water molecules
The problems such as casting, easily washed-away unbounded free acid at high temperature necessitate new methods of synthesis for HT-PEMFCs membranes. In addition to developing new kinds of materials, one can focus on the synthesis and preparation methods of already available membranes.

The mostly used base polymers have been PTFE, FEP, PVDF, ETFE, PE, PFA, and PVF. Moreover, styrene, AMS, TFS, substituted trifluorostyrene or other kinds of $\mathrm{N}$-containing heterocyclic monomers have been reported as grafted side chains in literature. In a limited number of studies from literature, the fuel cell performance of radiation induced-grafted proton exchange membranes was investigated as listed in Table 3. In this table, base polymer, monomer, graft level, specified fuel cell test conditions, and achieved maximum power density are reported.

N-vinylformamide, 1-vinylimidazole, and 4-vinyl pyridine(4-VP) were used as monomers, electron beam irradiated ETFE, or FEP films were employed as the base polymers to be applied in a radiation-induced grafted membrane which was subsequently doped with phosphoric acid [6]. In another study, a strong hydrogen bonding to $\mathrm{N}-\mathrm{H}$ groups of nitrogen-containing monomers, such as N-vinyl-2-pyrrolidone (NVP), 2-vinyl pyridine (2$V P)$, and 4-VP was reported for the purpose of radiation-induced grafting onto PTFE films [6].

A range of parameters has been reported to improve the membrane final performance. For example, radiation-induced grafting of 4-VP onto ETFE, which were electron beam irradiated, and finally doped by phosphoric acid. Here in the study, the effect of absorbed dose, monomer concentration, grafting temperature and time on the graft level have been investigated [6]. The membrane also had conductivities of $10-100 \mathrm{~ms}$ 
Table 3. Literature overview on membrane materials and fuel cell test results from studies focused on radiation grafted proton exchange membrane fuel cells.

\begin{tabular}{|c|c|c|c|c|c|}
\hline Base Polymer & Monomer & Degree of grafting & $\begin{array}{l}\text { Fuel cell test con- } \\
\text { dition }\end{array}$ & $\begin{array}{l}\text { Max. power density } \\
{\left[\mathrm{mW} \mathrm{cm}^{-2}\right]}\end{array}$ & References \\
\hline ETFE & 1-Vim & 113 & $\begin{array}{c}120^{\circ} \mathrm{C} \text {, no hum., } \\
\mathrm{H}_{2} / \mathrm{O}_{2}\end{array}$ & 150 & [83] \\
\hline ETFE & PVAm & 77 & $\begin{array}{c}120^{\circ} \mathrm{C} \text {, no hum., } \\
\mathrm{H}_{2} / \mathrm{O}_{2}\end{array}$ & 75 & [83] \\
\hline ETFE & $1-\mathrm{V} / \mathrm{m} / 4 \mathrm{VP}$ & 36 & $\begin{array}{c}120^{\circ} \mathrm{C}, 60 \% \text { hum., } \\
\mathrm{H}_{2} / \mathrm{O}_{2}\end{array}$ & 237 & [84] \\
\hline PVDF & PSSA & 35 & $\begin{array}{c}60^{\circ} \mathrm{C}, 80 \% \text { hum., } \\
\mathrm{H}_{2} / \mathrm{O}_{2}\end{array}$ & 250 & [58] \\
\hline ETFE & $4 \mathrm{VP}$ & 50 & $\begin{array}{c}100^{\circ} \mathrm{C}, 50 \% \text { hum., } \\
\mathrm{H}_{2} / \mathrm{O}_{2}\end{array}$ & 110 & [85] \\
\hline ETFE & $4 \mathrm{VP}$ & 45 & $\begin{array}{c}120^{\circ} \mathrm{C}, 50 \% \text { hum., } \\
\mathrm{H}_{2} / \mathrm{O}_{2}\end{array}$ & 510 & [75] \\
\hline
\end{tabular}

$\mathrm{cm}^{-1}$ at $25-120^{\circ} \mathrm{C}$ in dry conditions, high-temperature stability, and good mechanical strength. The power density of the synthesized membrane was up to 150 $\mathrm{mW} \mathrm{cm} \mathrm{cm}^{-2}$ (at $120^{\circ} \mathrm{C}$ and without humidification) [6].

Another example was radiation-induced grafting of 1-VIm and 4VP combination onto ETFE film followed by phosphoric acid doping. Figure 13 (left) demonstrates the detailed process. Ferrous salts were introduced during grafting to promote grafting reaction. High proton conductivity (50 $\mathrm{mS} \mathrm{cm}^{-1}$ at $20 \%$ humidity) and fuel cell performance ( $237 \mathrm{~mW} \mathrm{~cm}^{-2}$ ) were obtained for adopting this membrane [84]. As another example in which the phosphoric acid was used for doping of the prepared film was grafting of 4-VP onto PVDF film. This membrane has shown an electrochemical performance comparable with a similar process done on ETFE films [84].

Crosslinkers were introduced to enhance the stability and fuel cell performance of phosphoric acid-based radiation-grafted polymer membranes. Radiation-in-

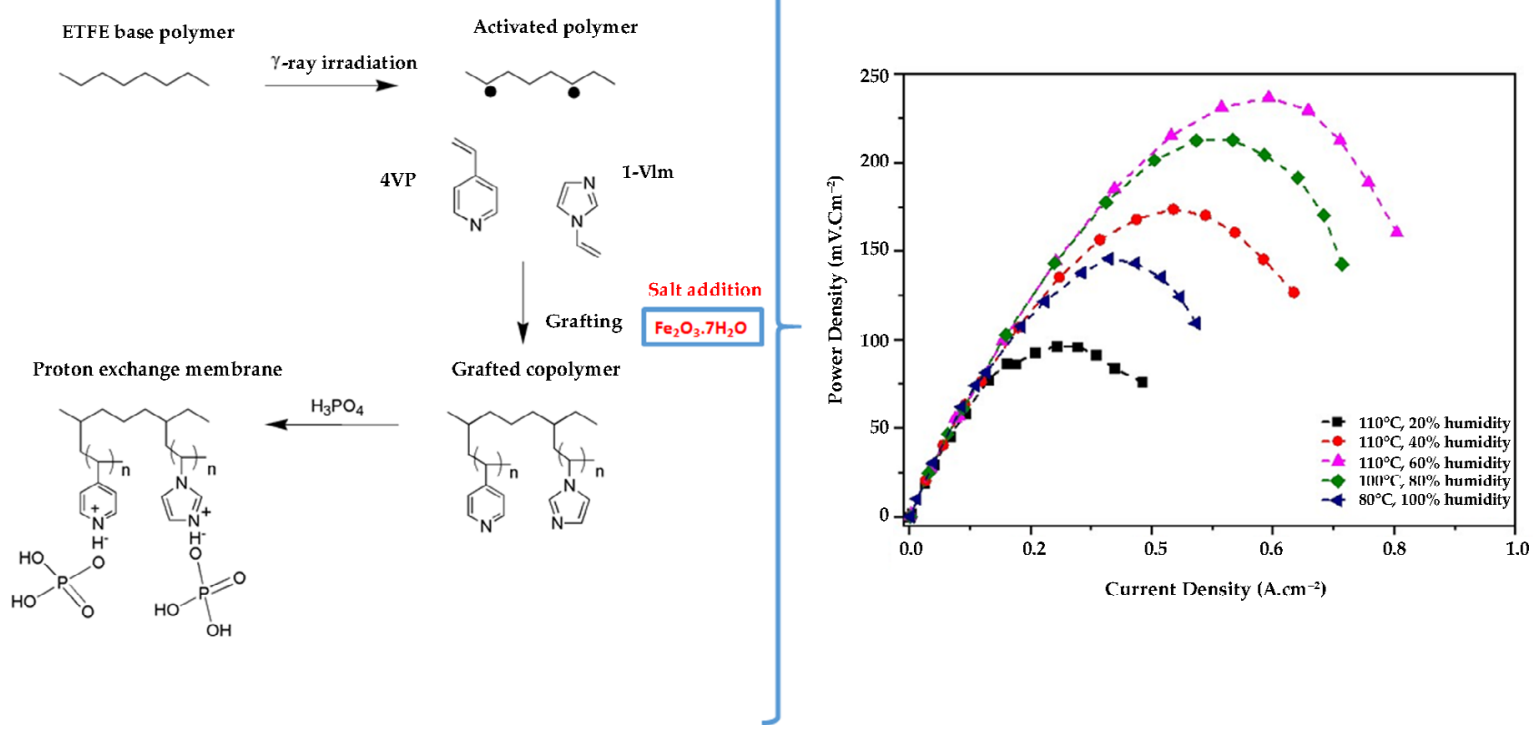

Figure 13. Schematic of phosphoric acid doped membranes preparation by radiation-induced grafting and subsequent acid doping (left) and fuel cell performance of these membranes (right) [84]. Reproduced with permission from ACS. 
(a)

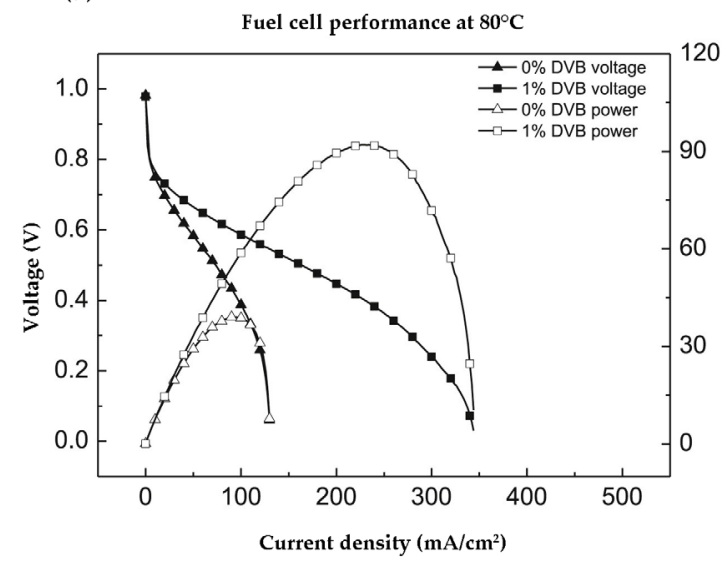

(b)

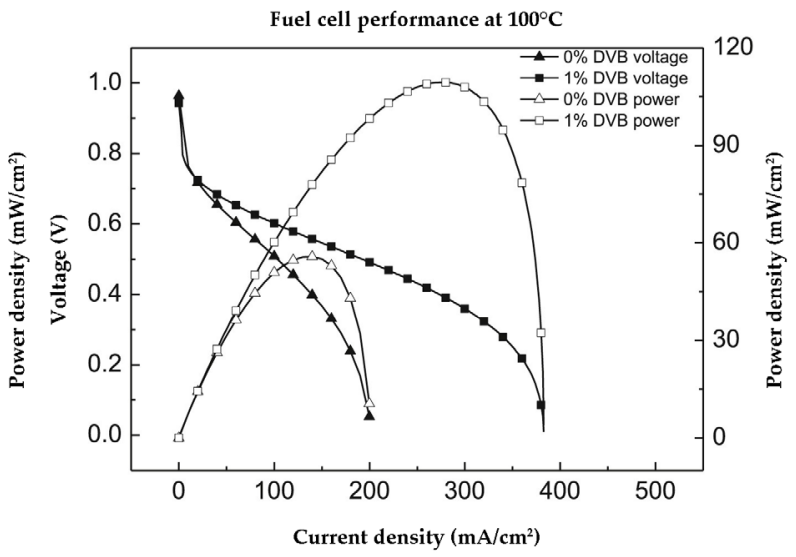

(c) Fuel cell performance at $120^{\circ} \mathrm{C}$

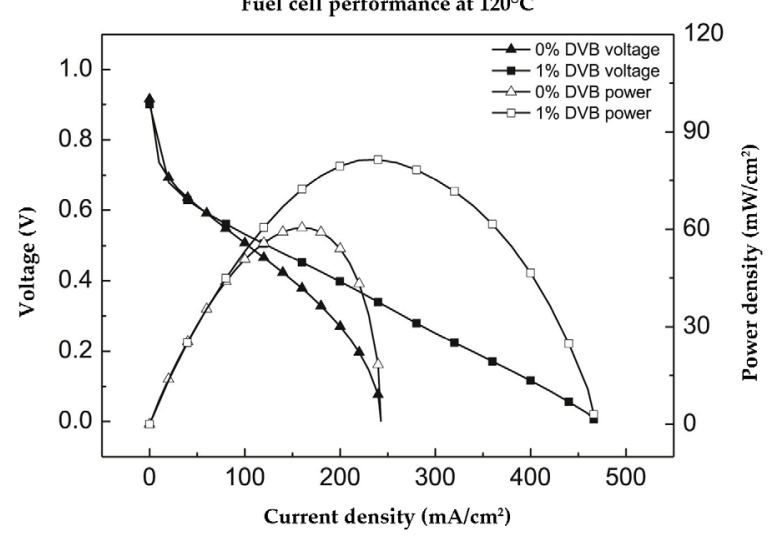

Figure 14. Fuel cell performance at $1 \mathrm{~atm}, 50 \% \mathrm{RH}$ for temperatures of (a) $80^{\circ} \mathrm{C}$ (b) $100^{\circ} \mathrm{C}$ (c) $120^{\circ} \mathrm{C}$; for uncrosslinked (\%O DVB) and crosslinked (1\% DVB) ETFE-g-4VP membranes [85]. Reproduced with permission from Elsevier Ltd.

duced grafting of 4VP onto ETFE films in the presence of DVB as the crosslinker and subsequent treatment of grafted films with phosphoric acid was reported [85]. It was shown that DVB crosslinked membranes demonstrated superior proton conductivity, mechanical properties, stability and fuel cell performance at high temperatures and low humidity conditions (Figure 14) [85].

\section{Anion Exchange Membranes (AEM) for AEMFC}

There is a significant interest in the development of materials for AEMFC due to its advantages such as a wide range of fuel selection, potential for non-noble catalysts (Pt-free), low-cost MEA fabrication, etc. The bottleneck for the development of better AEMFCs is AEM that provides the transport of $\mathrm{OH}^{-}$ions. The main problems of these membranes are i) low ionic conductivity due to the fact that the transport of $\mathrm{OH}^{-}$ions across the membrane is more difficult than $\mathrm{H}^{+}$ion compared to PEM; ii) low mechanical strength and chemical sta- bility; iii) high resistance which results in poor fuel cell performance; iv) high water absorption and swelling [86]. Due to these restrictions of AEM, the applicability and widespread use of AEM fuel cells are becoming difficult. It is known that commercial AEMs are remarkably obtained by radiation-induced grafting (e.g. Neosepta, Selemion, Fumasep, Ralex, Aciplex) that can be used in AEMFC applications [87]. Therefore, recent studies have been focused on new AEMs prepared with radiation-induced grafting technique [88-97].

The properties and synthesis of polymers used in anion exchange membranes directly affect the physical and chemical properties, stability, and cost of the membrane to be obtained. Polymer chemistry is the main factor that determines the properties of the AEM [98]. AEMs with block copolymer are widely used especially for the integration of hydrophobic phases into the membrane and to improve mechanical properties [99]. Cross- 


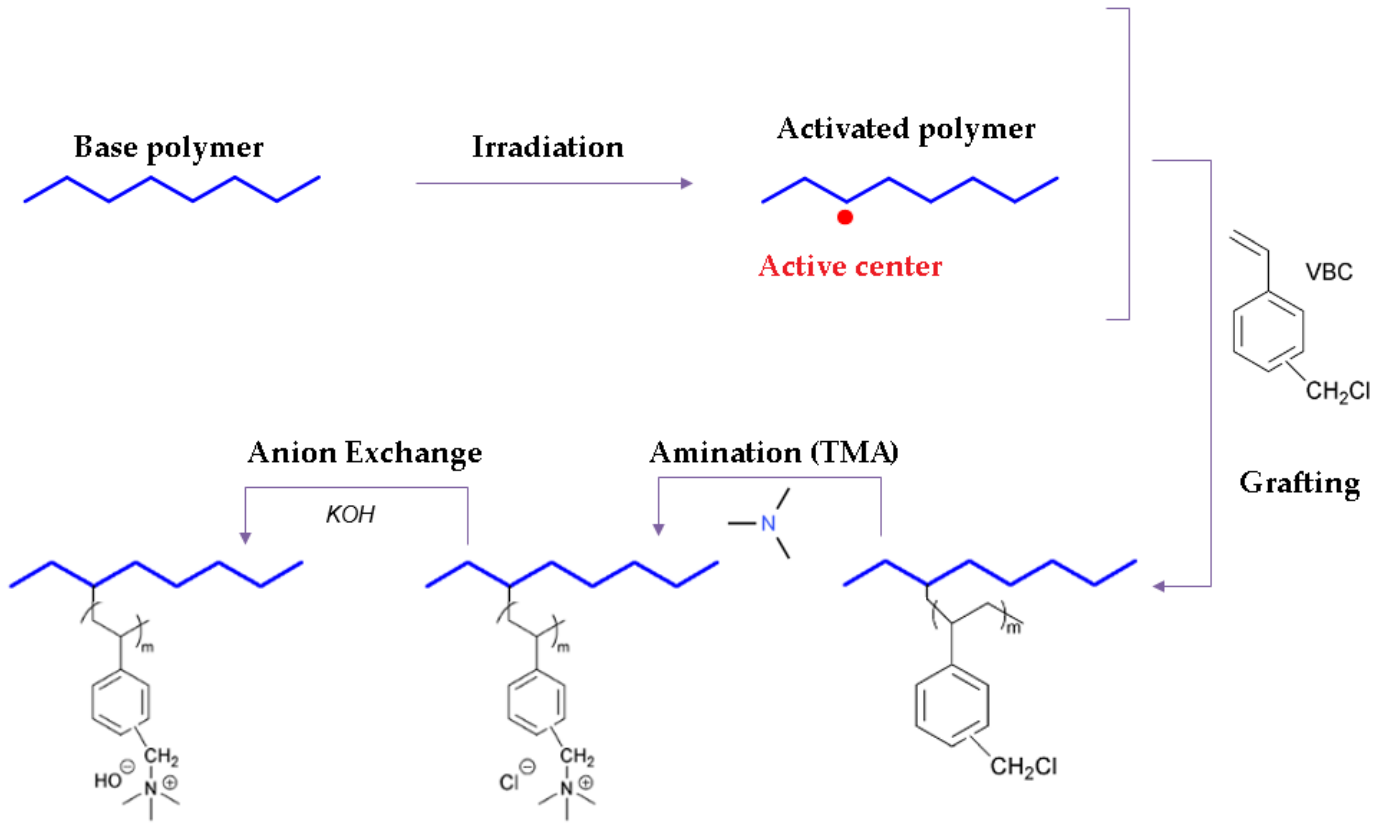

Anion Exchange

Membrane
Aminated polymer

Figure 15. Preparation of AEM by radiation-induced grafting of VBC onto base polymers and subsequent amination and alkalization [6]. Reproduced with permission from Elsevier Ltd.

linked polymers are also used to control swelling and enhanced mechanical stability. However, the crosslinking of AEM results in a decrease in the concentration of ionic groups, and the resulting membrane is more brittle $[99,100]$. In the literature, it has been reported that anion exchange membranes can be synthesized by classical radiation-induced grafting [101,102] as well as by free radical polymerization $[89,91,103]$. The synthesis of AEMs through radiation-induced grafting of monomers onto fluorinated, partially fluorinated, and non-fluorinated polymer films and powders have been extensively studied and reported to be an effective way of avoiding the use of hazardous chloromethyl ether which was widely used for the preparation of AEMs through chloromethylation of polymers, followed by quaternization and alkalization reactions [104-107]. Generally, ETFE, PVDF, and PE are the most studied base polymers for radiation grafted AEMs. These base polymers are irradiated with either e-beam or gamma irradiation processes [88-97].
AEMs synthesis with radiation-induced grafting generally carried out in three steps: i) forming active reaction centers (radicals) on the polymer surface by irradiating with high energy radiation, ii) initiating the polymerization reaction with a suitable vinyl monomer, iii) quaternization and alkalization reactions. The ionic property, water uptake, and conductivity of the membrane can be modified by controlling the degree of grafting with radiation-induced grafting [108]. By controlling these parameters, the mechanical strength of the AEM can also be controlled. Vinylbenzyl chloride $(V B C)$, as the monomer for grafting step due to its reactivity, trimethylamine for amination step, and potassium hydroxide for alkalization step were extensively employed (Figure 15).

In an early study in 2015, Poynton et al. used e-beam irradiated ETFE (poly(ethylene-co- tetrafluoroethylene)) films which are grafted with vinylbenzyl chloride (VBC) with various concentrations to study the optimal concentration and aminated with trimethylamine later. [88]. They were able to show that using a low concent- 
ration of VBC (20 vol.\% in propan-2-ol) at the grafting step was enough to provide as good fuel cell test results as an undiluted solution of VBC (100 vol.\%). Peak power densities around $164 \mathrm{~mW} \mathrm{~cm}^{-2}$ are reported for both membranes. This work opened a new way to scale up the membrane synthesis to $\mathrm{m}^{2}$ sized batches [88].

Wang et al. prepared several ETFE films based membranes by irradiation grafting of vinyl benzyl chloride (VBC) and amination with trimethylamine to optimize the synthesis route for RG-AEMs [89]. They reported that a high radiation dose decreases the mechanical strength of the membrane. Additionally, they were able to increase both ion exchange capacity and the anion conductivity due to a better graft distribution of the VBC by using water as the diluent at the grafting step. Their best performance membrane, which was radiated with 30 kGy doses and grafted with very low 5\% monomer volume, was able to provide peak power density as 1.16 $\mathrm{W} \mathrm{cm^{-2 }}$ at $60^{\circ} \mathrm{C}$ as a result of its high degree of grafting (76 wt\%) [89].

Later, another study on fluorinated AEMs conducted by Ponce-Gonzalez et al. focused on the increasing degree of grafting which also leads to better fuel cell performances by comparing the membranes prepared with different isomers of VBC (para-position, meta-position, and their commercially more available mixture) [90]. They prepared their membranes in a similar synthesis route with a $40 \mathrm{kGy}$ dose and $5 \%$ monomer concentration in water. $94 \%, 55 \%$, and $29 \%$ as degrees of grafting are achieved with 4- VBC, 3/4-VBC mixture, and 3-VBC, respectively, and hence parallel results with ion exchange capacities. They discussed that meta-only VBC is better for grafting due to less chain scission resulted from 1,6 elimination mechanism [90].

Alkaline exchange ionomers made out of ETFE powders were also investigated as well as film-based alkaline exchanged membranes [91]. One of the early studies of Poynton et al. used e-beam irradiated ETFE powders for ionomers, again grafted with vinyl benzyl chloride and aminated with trimethylamine. Their fuel cell test resulted in $240 \mathrm{~mW} \mathrm{~cm}^{-2}$ as peak power density which was low but led to a way to perform more ionomer research for alkaline polymer electrolyte fuel cells [91]. A more recent study conducted by Biancolli et al. investigated the performances of fuel cells made with anion exchange membrane ionomer powders using amination of VBC grafted ETFE with different head groups: trimethylamine (TMA), N-methylpyrrolidine (MPY), and $\mathrm{N}$-methylpiperidine (MPRD) [92]. They showed that MPRD based ionomer revealed the best result (peak power $1.43 \mathrm{~W} \mathrm{~cm}^{-2}$ ) among the head groups of this work which provided power densities around $1 \mathrm{~W} \mathrm{~cm}^{-2}$. Additionally, they reported that the high alkaline stability of MPRD based materials could lead to better AEMs [92].

Table 4. Literature overview on membrane preparation parameters and techniques extracted from studies focused on radiation grafted anion exchange membrane fuel cells.

\begin{tabular}{|c|c|c|c|c|c|}
\hline Base Polymer & $\begin{array}{l}\text { Radiation techni- } \\
\text { que and dose (kGy) }\end{array}$ & Monomer & $\begin{array}{l}\text { Concentration of } \\
\text { monomer (vol\%) }\end{array}$ & Amination & References \\
\hline ETFE film & e-beam 70 kGy & $3,4-V B C$ & $5-100$ & TMA & [88] \\
\hline ETFE film & e-beam 30 kGy & $3,4-V B C$ & 5 & TMA & [89] \\
\hline ETFE film & e-beam 40 kGy & $\begin{array}{c}\text { 3-VBC 4-VBC 3,4- } \\
\text { VBC }\end{array}$ & 5 & $\mathrm{TMA}$ & {$[90]$} \\
\hline ETFE powder & e-beam 70 kGy & $3,4-V B C$ & 20 & $\mathrm{TMA}$ & {$[91]$} \\
\hline ETFE powder & e-beam 30-40 kGy & $3,4-V B C$ & 5 & TMA, MPY, MPRD & {$[92]$} \\
\hline UHMWPE powder & p-ray $3-25$ kGy & $3,4-V B C$ & - & TMA & [93] \\
\hline UHMWPE powder & p-ray 5 kGy & $3,4-V B C$ & 50 & Guanidine & {$[94]$} \\
\hline LDPE film & p-ray $10-20$ kGy & $3,4-V B C$ & $10-33$ & TMA & {$[95]$} \\
\hline LDPE film & e-beam 50-100 & $3,4-V B C$ & 5 & TMA & {$[96]$} \\
\hline HDPE film & e-beam 10 kGy & $3,4-V B C$ & 5 & TMA & [97] \\
\hline
\end{tabular}


Table 5. Literature overview on membrane characterization results and fuel cell performances of extracted from studies focused on radiation grafted anion exchange membrane fuel cells.

\begin{tabular}{|c|c|c|c|c|c|}
\hline $\begin{array}{c}\text { Degree of Grafting } \\
\text { Mass (\%) }\end{array}$ & $\begin{array}{l}\text { Ion exchange } \\
\text { capacity }\end{array}$ & Water Uptake (\%) & $\begin{array}{l}\text { Ion conductivity } \\
\qquad\left(\mathrm{mS} \mathrm{cm}^{-1}\right)\end{array}$ & $\begin{array}{l}\text { Peak power density } \\
\qquad\left(\mathrm{W} \mathrm{cm}^{-2}\right)\end{array}$ & References \\
\hline- & $\begin{array}{c}1.34 \pm 0.19 \mathrm{mmol} \\
\mathrm{g}-1\end{array}$ & $43.5 \pm 2.5$ & $56 \pm 9$ & $0.164 \pm 3$ & [88] \\
\hline 76 & $2.01 \pm 0.02 \mathrm{mmol} \mathrm{g}^{-1}$ & $53 \pm 6$ & $60 \pm 2$ & 1.16 & [89] \\
\hline 61 & $1.88 \pm 0.02 \mathrm{mmol} \mathrm{g}^{-1}$ & $51 \pm 4$ & - & - & [90] \\
\hline- & $1.24 \pm 0.06 \mathrm{meq} \mathrm{g}^{-1}$ & $155.4 \pm 1.8$ & - & - & [91] \\
\hline- & $1.73 \pm 0.03 \mathrm{mmol} \mathrm{g}^{-1}$ & $84 \pm 8$ & $30.8 \pm 1.2$ & 1.43 & {$[92]$} \\
\hline 12.6 & 0.49 meq g $^{-1}$ & 17.46 & 47.5 & - & [93] \\
\hline 12.5 & $0.33 \mathrm{mmol} \mathrm{g}^{-1}$ & 5.72 & 27.7 & - & [94] \\
\hline 74.6 & $3.2 \mathrm{mmol} \mathrm{g}^{-1}$ & 285 & 120 & 0.68 & [95] \\
\hline 143 & $2.87 \pm 0.05 \mathrm{mmol} \mathrm{g}^{-1}$ & $104 \pm 9$ & 145 & 1.45 & {$[96]$} \\
\hline 170 & $2.44 \pm 0.04 \mathrm{mmol} \mathrm{g}^{-1}$ & $155 \pm 15$ & $214 \pm 2$ & 2.55 & [97] \\
\hline
\end{tabular}

Even though there are great developments of anion exchange membranes with radiation-induced grafted fluorinated polymers, the desired performances were still lacking mainly due to chain scission as a result of the stronger $\mathrm{C}-\mathrm{F}$ bond than $\mathrm{C}-\mathrm{C}$ bond. Additionally, fluorinated polymers didn't provide long alkaline stabilities and are easier to lose their mechanical properties at the lower doses of the radiation. Therefore, there is an interest in anion exchange membranes made out of lowcost non-fluorinated polymers like polyethylene which, however, were lacking the ionic conductivity. Hence, the study of Sherazi et al. in 2013 investigated an AEM made with ultra-high molecular weight polyethylene powder (UHMWPE) grafted with VBC after gamma radiation and cast into membranes then aminated with trimethylamine [93]. They could show long durability in an alkaline environment and they were able to increase the ionic conductivity up to $47 \mathrm{mS} \mathrm{cm}^{-1}$ at $90^{\circ} \mathrm{C}$ [93]

In a follow-up study, Sherazi et al. later in 2015 changed their functionalization method [94]. They prepared and characterized an anion exchange membrane by radiation grafting $V B C$ onto melt pressed membrane synthesized from ultra-high molecular weight polyethylene powder (UHMWPE) and functionalized it with 1,1,3,3-tetramethyl-2-n-butylguanidine (TMBG). Even though thermal stability and methanol permeability results were good, the ionic conductivity still was not enough for the fuel cells. However, it is also worth mentioning that their conductivity results were high for the low degrees of grafting and ion exchange capacities which showed the potential for better performances if a higher degree of grafting could be achieved [94].

Later, Espiritu et al. carried out a study on how important is to have a high degree of grafting for better performing anion exchange membranes [95]. Their low-density polyethylene films grafted with VBC were investigated with varying the parameters of the degree of grafting, film thickness, and gamma radiation dose. Ion conductivity was increased with an increase in both radiation dose as well as an increase in monomer concentrations. Linear low-density polyethylenes displayed a low degree of grafting in comparison to low-density polyethylenes as a result of the lack of chain branching. The highest conductivity of $0.12 \mathrm{~S} \mathrm{~cm}^{-1}$ at a temperature of $70^{\circ} \mathrm{C}$ was obtained with the membrane prepared from LDPE film with a degree of grafting of $71.3 \%$. The same membrane showed very high stability of 29 weeks during the alkaline stability test. Their best performing 
fuel cell test provided a peak power density of $608 \mathrm{~mW}$ $\mathrm{cm}^{-2}$ at $50^{\circ} \mathrm{C}[95]$

In 2017, Wang et al. compared low-density polyethylene (LDPE) based membranes to ETFE to investigate the importance of having a fluorinated backbone, and also they investigated the effect of the radiation dose on the mechanical properties of the membrane [96]. They used pre-irradiation in the air using an e-beam to craft VBC and aminated with benzyltrimethylammonium The LDPE membrane outperformed the ETFE in AEMFC tests by reaching $1.45 \mathrm{~W} \mathrm{~cm}^{-2}$ peak power density with a Pt/C cathode at $80^{\circ} \mathrm{C}$, and $931 \mathrm{~mW} \mathrm{~cm}^{-2}$ with $\mathrm{Ag} / \mathrm{C}$ cathode. The better performance of the LDPE is related to its high $\mathrm{OH}^{-}$conductivity of $145 \mathrm{~ms} / \mathrm{cm}$. Thermal stability of the LDPE allowing it to be functional at $80^{\circ} \mathrm{C}$ which increases the feasibility of the LDPE for AEMFC applications. Mechanical robustness after a high dose of e- beam irradiation is another advantage of the LDPE. ETFE gets weaker after the radiation due to the presence of C-F bonds of the backbone [96].

Wang et al. also investigated the difference in performances of using low (LDPE) or high-density polyethylene (HDPE) based membranes in 2019 [97]. $10 \mu \mathrm{m} \mathrm{HDPE}$ and $15 \mu \mathrm{m}$ LPDE films are subjected to a $100 \mathrm{kGy}$ radiation dose and the radiation-induced films are immersed and grafted with VBC, aminated with trimethylamine afterward. While they were only expecting better performances in terms of mechanical properties with HDPE relative to LDPE, HDPE membranes were able to provide better fuel cell performances, more durability in the alkaline environment in addition to expected enhanced mechanical properties, albeit they have comparable properties such as ion-exchange capacity (IEC), hydrated thickness, water-uptake, and $\mathrm{OH}$-conductivity. Their hypothesis is HPDE membranes have better water transportation which increases the performance drastically. HDPE membranes of their work provided the best peak power density of $2.5 \mathrm{~W} \mathrm{~cm}^{-2}$ [97].

Tables 4 and 5 summarize the membrane preparation parameters, techniques, characterization results, and fuel cell performances from the studies that are discussed in the previous parts.

\section{Conclusions}

Polymer electrolyte membranes are utilized as both separator and electrolyte in fuel cells. The membrane can be regarded as the heart of the fuel cell since the physicochemical nature of the membrane affects significantly the performance of the fuel cell. Ion conducting solid polymer electrolytes are employed for both PEMFC and AEMFC. An acidic-proton conducting polymer membrane in the former; an alkaline- hydroxide ion-conducting membrane is used in the latter. High conductivity, high chemical stability, mechanical integrity are the main requirements of those polymer membranes. Although there are commercially available polymer membranes for fuel cells, they possess certain drawbacks and limitations. Therefore, efforts are being made to develop membranes that have comparable performance and are available at an affordable price. Radiation-induced grafting is a promising method for the fabrication of alternative polymer membranes due to its lower cost of production, fine control on the grafting reaction parameters and membrane content, facile synthesis procedure, lower reaction temperature required for synthesis, no residues of initiator or catalyst, and applicability of any form of a polymer. It allows the use of a wide variety of base films and monomers which can be tailored for the desired end-use. The favorable and comparable fuel cell relevant and polarization properties containing such radiation-grafted membranes were reported. Thus, radiation-grafted polymer membranes are one of the significant low-cost alternatives for fuel cells.

\section{References}

1. Y. Wang, D.F. Ruiz Diaz, K.S. Chen, Z. Wang, X.C. Adroher, Materials, technological status, and fundamentals of PEM fuel cells - A review, Mater. Today, 32 (2020) 178-203.

2. L. Xing, W. Shi, H. Su, Q. Xu, P.K. Das, B. Mao, et al., Membrane electrode assemblies for PEM fuel cells: A review of functional graded design and optimization, Energy, 177 (2019) 445-64.

3. D.R. Dekel, Review of cell performance in anion exchange membrane fuel cells. J. Power Sources, 375 (2018) 158-69.

4. R. Borup, J. Meyers, B. Pivovar, Y.S. Kim, R. Mukundan, N. Garland, et al., Scientific aspects of polymer electrolyte fuel cell durability and degradation, Chem. Rev., 107 (2007) 3904-51.

5. J.R. Varcoe, P. Atanassov, D.R. Dekel, A.M. Herring, M.A. Hickner, P.A. Kohl, et al., Anion-exchange membranes in electrochemical energy systems, Energy Environ. Sci., 7 (2014) 3135-91.

6. M.M. Nasef, S.A. Gürsel, D. Karabelli, O. Güven, Radiationgrafted materials for energy conversion and energy storage applications, Prog. Polym. Sci., 63 (2016) 1-41.

7. S.J. Peighambardoust, S. Rowshanzamir, M. Amjadi, Review of the proton exchange membranes for fuel cell applications, Int. J. Hydrogen Energy, 35 (2010) 9349-84. 
8. L. Gubler, N. Beck, S.A. Gürsel, F. Hajbolouri, D. Kramer, A Reiner, et al., Materials for polymer electrolyte fuel cells, Chim. Int. J. Chem., 58 (2004) 826-36.

9. L. Gubler, G.G. Scherer, Trends for fuel cell membrane development, Desalination, 250 (2010) 1034-1037.

10. K.A. Mauritz, R.B. Moore, State of understanding of nafion, Chem. Rev., 104 (2004) 4535-4586.

11. K. Schmidt-Rohr, Q. Chen, Parallel cylindrical water nanochannels in nafion fuel-cell membranes, Nat. Mater., 7 (2008) 75-83.

12. B.P. Tripathi, V.K. Shahi, Organic-inorganic nanocomposite polymer electrolyte membranes for fuel cell applications, Prog. Polym. Sci., 36 (2011) 945-79.

13. L. Gubler, S.A. Gürsel, G.G. Scherer, Radiation grafted membranes for polymer electrolyte fuel cells, Fuel Cells, 5 (2005) 317-35.

14. L. Gubler, G.G. Scherer, Durability of radiation-grafted fuel cell membranes, Polym. electrolyte fuel cell Durab. Springer; 2009, p. 133-55.

15. M.M. Nasef, E.S.A. Hegazy, Preparation and applications of ion exchange membranes by radiation-induced graft copolymerization of polar monomers onto non-polar films, Prog. Polym. Sci., 29 (2004) 499-561.

16. M.M. Nasef, O. Güven, Radiation-grafted copolymers for separation and purification purposes: Status, challenges and future directions, Prog. Polym. Sci., 37 (2012) 1597-656.

17. S.A. Gürsel, A. Wokaun, G.G. Scherer, Influence of reaction parameters on grafting of styrene into poly (ethylene-alttetrafluoroethylene) films, Nucl. Instrum. Methods Phys. Res., Sect. B, 265 (2007) 198-203.

18. M. Paronen, F. Sundholm, E. Rauhala, T. Lehtinen, S. Hietala, Effects of irradiation on sulfonation of poly(vinyl fluoride), J. Mater. Chem. 7 (1997) 2401-2406.

19. W.K. Fisher, J.C. Corelli, Effect of ionizing radiation on the chemical composition, crystalline content and structure, and flow properties of polytetrafluoroethylene, J. Polym. Sci., Part A: Polym. Chem., 19 (1981) 2465-2493.

20. K. Lunkwitz, H.J. Brink, D. Handte, A. Ferse, The radiation degradation of polytetrafluoroethylene resulting in lowmolecular and functionalized perfluorinated compounds, Int. J. Radiat. Appl. Instrum. Part C, 33 (1989) 523-32.

21. W. Bürger, K, Lunkwitz, G. Pompe, A. Petr, D. Jehnichen, Radiation degradation of fluoropolymers: Carboxylated fluoropolymers from radiation degradation in presence of air, J. Appl. Polym. Sci., 48 (1993) 1973-85.

22. U.Lappan, L. Häußler, G. Pompe, K. Lunkwitz, Thermalstability of electron beam-irradiated polytetrafluoroethylene, J. Appl. Polym. Sci., 66 (1997) 2287-91.

23. D.J.T. Hill, S. Mohajerani, P.J. Pomery, A.K. Whittaker, An ESR study of the radiation chemistry of poly (tetrafluoroethylene-co-hexafluoropropylene) at 77 and 300 K, Radiat. Phys. Chem., 59 (2000) 295-302.

24. T.R. Dargaville, D.J.T. Hill, A.K. Whittaker, An ESR study of irradiated poly(tetrafluoroethylene-co-perfluoropropyl vinyl ether) (PFA), Radiat. Phys. Chem., 62 (2001) 25-31.

25. A. Oshima, T. Seguchi, Y. Tabata, ESR study on free radicals trapped in crosslinked polytetrafluoroethylene (PTFE), Radiat. Phys. Chem., 50 (1997) 601-6.

26. K. Lunkwitz, U. Lappan, D. Lehmann, Modification of fluoropolymers by means of electron beam irradiation, Radiat. Phys. Chem., 57 (2000) 373-376.

27. H.P. Brack, H.G. Buhrer, L. Bonorand, G.G. Scherer, Grafting of pre-irradiated poly(ethylene-alt-tetrafluoroethylene) films with styrene: Influence of base polymer film properties and processing parameters, J. Mater. Chem., 10 (2000) 1795-1803.
28. N. Walsby, F. Sundholm, T. Kallio, G. Sundholm, Radiationgrafted ion-exchange membranes: Influence of the initial matrix on the synthesis and structure, J. Polym. Sci., Part A: Polym. Chem., 39 (2001) 3008-17.

29. J. Chen, M. Asano, Y. Maekawa, M. Yoshida, Suitability of some fluoropolymers used as base films for preparation of polymer electrolyte fuel cell membranes, J. Membr. Sci., 277 (2006) 249-257.

30. J. Chen, U. Septiani, M. Asano, Y. Maekawa, H. Kubota, M. Yoshida, Comparative study on the preparation and properties of radiation-grafted polymer electrolyte membranes based on fluoropolymer films, J. Appl. Polym. Sci., 103 (2007) 1966-1972.

31. E.A. Hegazy, I. Ishigaki, J. Okamoto, Radiation grafting of acrylic acid onto fluorine-containing polymers, I. Kinetic study of preirradiation grafting onto poly(tetrafluoroethylene), J. Appl. Polym. Sci., 26 (1981) 3117-3124.

32. H.P. Brack, G.G. Scherer, Modification and characterization of thin polymer films for electrochemical applications, Macromol. Symp., 126 (1998) 25-49.

33. T. Momose, H. Yoshioka, I. Ishigaki, J. Okamoto, Radiation grafting of $\alpha, \beta, \beta$-trifluorostyrene onto poly(ethylenetetrafluoroethylene) film by preirradiation method, II. Properties of cation-exchange membrane obtained by sulfonation and hydrolysis of the grafted film, J. Appl. Polym. Sci., 38 (1989) 2091-101.

34. A.Chapiro, Préparation des copolymères greffés du polytetrafluoroéthylène (Teflon) par voie radiochimique, J. Polym. Sci., 34 (1959) 481-501.

35. B. Gupta, G.G.Scherer, Proton-exchange membranes by radiation-induced graft-copolymerization of monomers into teflon-fep films, Chimia, 48 (1994) 127-137.

36. S.A. Guersel, L. Gubler, B. Gupta, G.G.Scherer, Radiation grafted membranes. Fuel cells I, Springer; 2008, p. 157-217.

37. S. Phadnis, M. Patri, V.R. Hande, P.C. Deb, Proton exchange membranes by grafting of styrene-acrylic acid onto FEP by preirradiation technique, I. Effect of synthesis conditions, J. Appl. Polym. Sci., 90 (2003) 2572-7.

38. G.Z. Liang, T.L. Lu, X.Y. Ma, H.X. Yan, Z.H. Gong, Synthesis and characteristics of radiation-grafted membranes for fue cell electrolytes, Polym. Int., 52 (2003) 1300-1308.

39. T. Rager, Pre-irradiation grafting of styrene/divinylbenzene onto poly(tetrafluoroethylene-co-hexafluoropropylene) from non-solvents, Helv. Chim. Acta, 86 (2003) 1966-1981.

40. M.M. Nasef, Effect of solvents on radiation-induced grafting of styrene onto fluorinated polymer films, Polym. Int., 50 (2001) 338-346.

41. M.M. Nasef, H. Saidi, H.M. Nor, O.M. Foo, Proton exchange membranes prepared by simultaneous radiation grafting of styrene onto poly(tetrafluoroethylene-cohexafluoropropylene) films, II. Properties of sulfonated membranes, J. Appl. Polym. Sci., 78 (2000) 2443-2453.

42. M.M. Nasef, H. Saidi, Preparation of crosslinked cation exchange membranes by radiation grafting of styrene/ divinylbenzene mixtures onto PFA films, J. Membr. Sci., 216 (2003) 27-38.

43. T.R. Dargaville, G.A. George, D.J.T. Hill, A.K. Whittaker, High energy radiation grafting of fluoropolymers, Prog. Polym. Sci., 28 (2003) 1355-76.

44. T. Rager, Parameter study for the pre-irradiation grafting of styrene/divinylbenzene onto poly(tetrafluoroethyleneco-hexafluoropropylene) from isopropanol solution, Helv. Chim. Acta, 87 (2004) 400-407.

45. F.N. Büchi, B. Gupta, O. Haas, G.G. Scherer, Study of radiation-grafted FEP-G-polystyrene membranes as polymer electrolytes in fuel cells, Electrochim. Acta, 40 (1995) 345-353. 
46. M.V. Rouilly, E.R. Kötz, O. Haas, G.G. Scherer, A. Chapiró, Proton exchange membranes prepared by simultaneous radiation grafting of styrene onto Teflon-FEP films. Synthesis and characterization, J. Membr. Sci., 81 (1993) 89-95.

47. B. Gupta, F.N. Büchi, M. Staub, D. Grman, G.G. Scherer, Cation exchange membranes by pre-irradiation grafting of styrene into FEP films, II. Properties of copolymer membranes, J. Polym. Sci., Part A: Polym. Chem., 34 (1996) 1873-1880.

48. B. Gupta, N. Anjum, A.P. Gupta, Development of membranes by radiation grafting of acrylamide into polyethylene films: Influence of synthesis conditions, J. Appl. Polym. Sci., 77 (2000) 1331-1337.

49. F. Cardona, G.A. George, D.J.T. Hill, F. Rasoul, J. Maeji, Copolymers obtained by the radiation-induced grafting of styrene onto poly(tetrafluoroethylene-coperfluoropropylvinyl ether) substrates, 1. Preparation and structural investigation, Macromolecules, 35 (2002) 355364.

50. F. Cardona, G.A. George, D.J.T. Hill, S. Perera, Spectroscopic study of the penetration depth of grafted polystyrene onto poly(tetrafluoroethylene-co-perfluoropropylvinylether) substrates, 1. Effect of grafting conditions, J. Polym. Sci., Part A: Polym. Chem., 40 (2002) 3191-3199.

51. C.A. Finch, Polymer handbook: Third edition Edited by J. Brandrup and E. H. Immergut, Wiley-Interscience, Chichester, 1989. pp. ix + parts I to VIII, ISBN 0-471-812447. Br Polym J 1990;23:277-277.

52. E.A. Hegazy, N.H. Taher, H. Kamal, Preparation and properties of cationic membranes obtained by radiation grafting of methacrylic acid onto PTFE films, J. Appl. Polym. Sci., 38 (1989) 1229-1242.

53. N. Walsby, M. Paronen, J. Juhanoja, F. Sundholm, Sulfonation of styrene-grafted poly(vinylidene fluoride) films, J. Appl. Polym. Sci., 81 (2001) 1572-1580.

54. L. Gubler, N. Prost, S.A. Gürsel, G.G. Scherer, Proton exchange membranes prepared by radiation grafting of styrene/divinylbenzene onto poly (ethylene-alttetrafluoroethylene) for low temperature fuel cells, Solid State lonics, 176 (2005) 2849-2860.

55. L. Gubler, S.A. Gürsel, A. Wokaun, G.G. Scherer, Cross-linker effect in ETFE-based radiation-grafted proton-conducting membranes: I. Properties and fuel cell performance characteristics, J. Electrochem. Soc., 155 (2008) B921.

56. L. Gubler, T. Yamaki, S. Sawada, S.A. Gürsel, A. Wokaun, G.G. Scherer, Cross-linker effect in ETFE-based radiation-grafted proton-conducting membranes: II. Extended fuel cell operation and degradation analysis, J. Electrochem. Soc. 156 (2009) B532.

57. T. Yamaki, S. Sawada, M. Asano, Y. Maekawa, M. Yoshida, L. Gubler, et al., Fuel-cell performance of multiply-crosslinked polymer electrolyte membranes prepared by two-step radiation technique, ECS Trans., 25 (2009) 1439.

58. S. Sadeghi, L. Işıkel Şanlı, E. Güler, S. Alkan Gürsel, Enhancing proton conductivity via sub-micron structures in proton conducting membranes originating from sulfonated PVDF powder by radiation-induced grafting, Solid State Ionics, 314 (2018) 66-73.

59. A.B. LaConti, M. Hamdan, R.C. McDonald, Mechanisms of membrane degradation, Handb Fuel Cells 2010.

60. G. Hübner, E. Roduner, EPR investigation of $\mathrm{HO} /$ radical initiated degradation reactions of sulfonated aromatics as model compounds for fuel cell proton conducting membranes, J. Mater. Chem., 9 (1999) 409-418.

61. S. Alkan Gürsel, Z. Yang, B. Choudhury, M.G. Roelofs, G.G. Scherer, Radiation-grafted membranes using a trifluorostyrene derivative, J. Electrochem. Soc., 153 (2006) A1964.
62. L. Gubler, S.A. Gürsel, D. Henkensmeier, A. Wokaun, G.G. Scherer, Novel ETFE based radiation grafted poly (styrene sulfonic acid-co-methacrylonitrile) proton conducting membranes with increased stability, Electrochem. Commun., 11 (2009) 941-4.

63. B. Gupta, F.N. Büchi, G.G. Scherer, A. Chapiro, Materials research aspects of organic solid proton conductors, Solid State lonics, 61 (1993) 213-8.

64. F.N. Büchi, B. Gupta, O. Haas, G.G. Scherer, Performance of differently cross-linked, partially fluorinated proton exchange membranes in polymer electrolyte fuel cells, J. Electrochem. Soc., 142 (1995) 3044.

65. B. Gupta, G.G. Scherer, J.G. Highfield, Thermal stability of proton exchange membranes prepared by grafting of styrene into pre-irradiated FEP films and the effect of crosslinking, Die Angew. Makromol. Chemie., 256 (1998) 81-4.

66. P. Farquet, C. Padeste, M. Börner, S.A. Gürsel, G.G. Scherer, H.H. Solak, et al., Microstructured proton-conducting membranes by synchrotron-radiation-induced grafting, J. Membr. Sci., 325 (2008) 658-64.

67. D.E. Curtin, R.D. Lousenberg, T.J. Henry, P.C. Tangeman, M.E. Tisack, Advanced materials for improved PEMFC performance and life, J. Power Sources, 131 (2004) 41-8.

68. K. Enomoto, S. Takahashi, T. Iwase, T. Yamashita, Y. Maekawa, Degradation manner of polymer grafts chemically attached on thermally stable polymer films: Swelling-induced detachment of hydrophilic grafts from hydrophobic polymer substrates in aqueous media, J. Mater. Chem., 21 (2011) 9343-9.

69. M.M. Nasef, H. Saidi, Structure-property relationships in radiation grafted poly(tetrafluoroethylene)-graftpolystyrene sulfonic acid membranes, J. Polym. Res., 12 (2005) 305-12.

70. K.D. Kreuer, On the development of proton conducting polymer membranes for hydrogen and methanol fuel cells, J. Membr. Sci., 185 (2001) 29-39.

71. V. Saarinen, T. Kallio, M. Paronen, P. Tikkanen, E. Rauhala, K. Kontturi, New ETFE-based membrane for direct methanol fuel cell, Electrochim. Acta, 50 (2005) 3453-60.

72. C. Chuy, V.I. Basura, E. Simon, S. Holdcroft, J. Horsfall, K.V. Lovell, Electrochemical characterization of ethylenetetrafluoroethylene-g-polystyrenesulfonic acid solid polymer electrolytes, J. Electrochem. Soc., 147 (2000) 4453.

73. K.D. Kreuë, On the development of proton conducting materials for technological applications, Solid State Ionics, 97 (1997) 1-15.

74. L. Gubler, H. Kuhn, T.J. Schmidt, G.G. Scherer, H.P. Brack, K. Simbeck, Performance and durability of membrane electrode assemblies based on radiation-grafted FEP-gpolystyrene membranes, Fuel Cells, 4 (2004) 196-207.

75. L.I. Sanli, S. Tas, Y. Yürüm, S.A. Gürsel, Water free operated phosphoric acid doped radiation-grafted proton conducting membranes for high temperature polymer electrolyte membrane fuel cells, Fuel Cells, 14 (2014) 914-25.

76. R.E. Rosli, A.B. Sulong, W.R.W. Daud, M.A. Zulkifley, T. Husaini, M.I. Rosli, et al., A review of high-temperature proton exchange membrane fuel cell (HT-PEMFC) system, Int. J. Hydrogen Energy, 42 (2017) 9293-314.

77. C. Wieser, Novel polymer electrolyte membranes for automotive applications - Requirements and benefits, Fuel Cells, 4 (2004) 245-50.

78. J. Zhang, Z. Xie, J. Zhang, Y. Tang, C. Song, T. Navessin, et al., High temperature PEM fuel cells, J. Power Sources, 160 (2006) 872-891. 
79. C. Song, Y. Tang, J.L. Zhang, J. Zhang, H. Wang, J. Shen, et al., PEM fuel cell reaction kinetics in the temperature range of 23-120 ${ }^{\circ} \mathrm{C}$, Electrochim. Acta, 52 (2007) 2552-2561.

80. A. Chandan, M. Hattenberger, A. El-Kharouf, S. Du, A. Dhir, V. Self, et al., High temperature (HT) polymer electrolyte membrane fuel cells (PEMFC)-A review, J. Power Sources, 231 (2013) 264-278.

81. S. Bose, T. Kuila, T.X.H. Nguyen, N.H. Kim, K.T. Lau, J.H. Lee, Polymer membranes for high temperature proton exchange membrane fuel cell: Recent advances and challenges, Prog. Polym. Sci., 36 (2011) 813-843.

82. B. Smitha, S. Sridhar, A.A. Khan, Solid polymer electrolyte membranes for fuel cell applications - A review, J. Membr. Sci., 259 (2005) 10-26.

83. C. Schmidt, G. Schmidt-Naake, Proton conducting membranes obtained by doping radiation-grafted basic membrane matrices with phosphoric acid, Macromol. Mater. Eng., 292 (2007) 1164-1175.

84. N. Rajabalizadeh Mojarrad, S. Sadeghi, B. Yarar Kaplan, E. Güler, S. Alkan Gürsel, Metal-salt enhanced grafting of vinylpyridine and vinylimidazole monomer combinations in radiation grafted membranes for high-temperature PEM fuel cells, ACS Appl. Energy Mater., 3 (2020) 532-40.

85. E. Güler, S. Sadeghi, S. Alkan Gürsel, Characterization and fuel cell performance of divinylbenzene crosslinked phosphoric acid doped membranes based on 4-vinylpyridine grafting onto poly(ethylene-co-tetrafluoroethylene) films, Int. J. Hydrogen Energy, 43 (2018) 8088-8099.

86. S. Gottesfeld, D.R. Dekel, M. Page, C. Bae, Y. Yan, P. Zelenay, et al., Anion exchange membrane fuel cells: Current status and remaining challenges, J. Power Sources, 375 (2018) 170184.

87. G. Merle, M. Wessling, K. Nijmeijer, Anion exchange membranes for alkaline fuel cells: A review. J. Membr. Sci., 377 (2011) 1-35.

88. S.D. Poynton, J.R. Varcoe, Reduction of the monomer quantities required for the preparation of radiation-grafted alkaline anion-exchange membranes, Solid State Ionics, 277 (2015) 38-43.

89. L. Wang, E. Magliocca, E.L. Cunningham, W.E. Mustain, S.D. Poynton, R. Escudero-Cid, et al., An optimised synthesis of high performance radiation-grafted anion-exchange membranes, Green Chem., 19 (2017) 831-843.

90. J. Ponce-González, J.R. Varcoe, D.K. Whelligan, Commercial monomer availability leading to missed opportunities? anion-exchange membranes made from meta-vinylbenzyl chloride exhibit an alkali stability enhancement, ACS Appl. Energy Mater., 1 (2018) 1883-7.

91. S.D. Poynton, R.C.T. Slade, T.J. Omasta, W.E. Mustain, R. Escudero-Cid, P. Ocón, et al., Preparation of radiationgrafted powders for use as anion exchange ionomers in alkaline polymer electrolyte fuel cells, J. Mater. Chem. A, 2 (2014) 5124-5130.

92. A.L.G. Biancolli, D. Herranz, L. Wang, G. Stehlíková, R. Bance-Soualhi, J. Ponce-González, et al., ETFE-based anion-exchange membrane ionomer powders for alkaline membrane fuel cells: A first performance comparison of head-group chemistry, J. Mater. Chem. A, 6 (2018) 24330 24341.

93. T.A. Sherazi, J. Yong Sohn, Y. Moo Lee, M.D. Guiver, Polyethylene-based radiation grafted anion-exchange membranes for alkaline fuel cells, J. Membr. Sci., 441 (2013) 148-157.
94. T.A. Sherazi, S. Zahoor, R. Raza, A.J. Shaikh, S.A.R. Naqvi, G. Abbas, et al., Guanidine functionalized radiation induced grafted anion-exchange membranes for solid alkaline fuel cells, Int. J. Hydrogen Energy, 40 (2015) 786-796.

95. R. Espiritu, M. Mamlouk, K. Scott, Study on the effect of the degree of grafting on the performance of polyethylene-based anion exchange membrane for fuel cell application, Int. J. Hydrogen Energy, 41 (2016) 1120-1133.

96. L. Wang, J.J. Brink, Y. Liu, A.M. Herring, J. Ponce-González, D.K. Whelligan, et al., Non-fluorinated pre-irradiation-grafted (peroxidated) LDPE-based anion-exchange membranes with high performance and stability, Energy Environ. Sci., 10 (2017) 2154-2167.

97. L. Wang, X. Peng, W.E. Mustain, J.R. Varcoe, Radiation-grafted anion-exchange membranes: The switch from low- to highdensity polyethylene leads to remarkably enhanced fuel cell performance, Energy Environ. Sci., 12 (2019) 1575-1579.

98. G. Couture, A. Alaaeddine, F. Boschet, B. Ameduri, Polymeric materials as anion-exchange membranes for alkaline fuel cells, Prog. Polym. Sci., 36 (2011) 1521-1557.

99. S. Subianto, M. Pica, M. Casciola, P. Cojocaru, L. Merlo, G. Hards, et al., Physical and chemical modification routes leading to improved mechanical properties of perfluorosulfonic acid membranes for PEM fuel cells, J. Power Sources, 233 (2013) 216-230.

100. N.J. Robertson, H.A. Kostalik, IV, T.J. Clark, P.F. Mutolo, H.D. Abruña, G.W. Coates, Tunable high performance cross-linked alkaline anion exchange membranes for fuel cell applications, J. Am. Chem. Soc., 132 (2010) 3400-3404.

101. H.S. Dang, E.A. Weiber, P. Jannasch, Poly(phenylene oxide) functionalized with quaternary ammonium groups via flexible alkyl spacers for high-performance anion exchange membranes, J. Mater. Chem. A, 3 (2015) 5280-5284.

102. M. Guo, J. Fang, H. Xu, W. Li, X. Lu, C. Lan, et al., Synthesis and characterization of novel anion exchange membranes based on imidazolium-type ionic liquid for alkaline fuel cells, J. Membr. Sci., 362 (2010) 97-104.

103. J. Ponce-González, I. Ouachan, J.R. Varcoe, D.K. Whelligan, Radiation-induced grafting of a butyl-spacer styrenic monomer onto ETFE: The synthesis of the most alkali stable radiation-grafted anion-exchange membrane to date, J. Mater. Chem. A, 6 (2018) 823-827.

104. S. Lu, J. Pan, A. Huang, L. Zhuang, J. Lu, Alkaline polymer electrolyte fuel cells completely free from noble metal catalysts, Proc. Natl. Acad. Sci. U. S. A., 105 (2008) 20611-20614.

105. E.N. Komkova, D.F. Stamatialis, H. Strathmann, M. Wessling, Anion-exchange membranes containing diamines: Preparation and stability in alkaline solution, J. Membr. Sci., 244 (2004) 2534.

106. Y. Xiong, J. Fang, Q.H. Zeng, Q.L. Liu, Preparation and characterization of cross-linked quaternized poly(vinyl alcohol) membranes for anion exchange membrane fuel cells, J. Membr. Sci., 311 (2008) 319-325.

107. G. Wang, Y. Weng, D. Chu, D. Xie, R. Chen, Preparation of alkaline anion exchange membranes based on functional poly(ether-imide) polymers for potential fuel cell applications, J. Membr. Sci., 326 (2009) 4-8.

108. T. Zhou, R. Shao, S. Chen, X. He, J. Qiao, J. Zhang, A review of radiation-grafted polymer electrolyte membranes for alkaline polymer electrolyte membrane fuel cells, J. Power Sources, 293 (2015) 946-975. 